\title{
INTERPRETATIVE RULES WITH LEGISLATIVE EFFECT: AN ANALYSIS AND A PROPOSAL FOR PUBLIC PARTICIPATION
}

\author{
KEVIN W. SAUNDERS*
}

Administrative law recognizes a distinction between legislative and interpretative rules. ${ }^{1}$ Until recently, legislative rules differed from interpretative rules in content, the authority under which each kind was promulgated, and the procedure adininistrative agencies followed in promulgating them. An interpretative rule stated what the agency thought the statute meant. ${ }^{2}$ Since the rule merely articulated rights and duties already implicit in the statute and did not create new ones, ${ }^{3}$ the agency needed no delegated authority to promulgate it. ${ }^{4}$ Because the interpretation itself lacked the force of law and its validity could be challenged before a reviewing court, an agency could adopt it without procedures involving public participation. ${ }^{5} \mathrm{~A}$ legislative rule, in contrast, created rights and duties im addition to those embodied in the statute. ${ }^{6}$ The agency administering the statute could only adopt this kind of

* Assistant Professor of Law, University of Arkansas, Fayetteville, Arkansas. A.B., Franklin \& Marshall College; M.S., M.A., Ph.D., University of Miami; J.D., University of Michigan. The author wishes to express his gratitude to the Honorable Kenneth W. Starr, United States Court of Appeals for the District of Columbia Circuit, for his valuable comments on earlier drafts of this article.

1. See 5 U.S.C. $\$$ 553(b) (1982). See generally 2 K. Davis, Administrative LaW TreatiSE $\S \S$ 7:7-:13, at 36-64 (2d ed. 1979 \& Supp. 1982).

2. See, e.g., Skidmore v. Swift \& Co., 323 U.S. 134, 138 (1944) ("[Interpretative rules] provide a guide ... as to how [the agency] will seek to apply [the statute]."); Gibson Wine Co. v. Snyder, 194 F.2d 329, 331 (D.C. Cir. 1952) ("[I]nterpretative rules are statements as to what the [agency] thinks the statute ... means.").

3. See, e.g., Alcarez v. Block, 746 F.2d 593, 613 (9th Cir. 1984) (legislative rules "create law ... incrementally imposing general, extra-statutory obligations .... [I]nterpretative rules ... mercly clarify or explain existing law or regulations.") (citations omitted).

4. See, e.g., General Elec. Co. v. Gilbert, 429 U.S. 125, 141 (1976) (“Congress . . . did not confer upon [the agency] authority to promulgate rules or regulations .... This does not mean that [agency] guidelines are not entitled to consideration in determining legislative intent.") (citations omitted).

5. Courts were not obligated to give interpretative rules legislative effect. Instead, they gave deference to such rules. The extent to which a court deferred to an agency's interpretation depended in part on the thoroughness of the procedure followed in adopting the rule. See Skidmore v. Swift \& Co., 323 U.S. 134, 140 (1944). In contrast, a court has no choice to defer or not to legislative rules. It is bound to give these rules controlling effect. See infra notes 104-17 and aecompanying text.

6. See, e.g., Batterton v. Francis, 432 U.S. 416, 425 \& n.9 (1977). 
rule when Congress had delegated to it the authority to do so. ${ }^{7}$ And because courts accorded these rules the force of law, ${ }^{8}$ agencies had to follow notice and comment procedures in adopting them. ${ }^{9}$

This congruence of content, authority, and procedure has gradually fallen out of balance. First, there has always been doubt whether one could reliably tell the difference between a rule that interpreted a statute and one that extrapolated from the statute. ${ }^{10}$ Furthermore, courts have begun to recognize that Congress sometimes implicitly delegates authority to make rules with legislative effect. ${ }^{11}$ Implicit delegations mean one cannot depend on the express terms of the statute to decide if rules promulgated to implement it have legislative effect. Finally, and most recently, the United States Court of Appeals for the District of Columbia Circuit has indicated that the procedure an agency follows in promulgating a rule does not control whether the rule has legislative effect. ${ }^{12}$ In General Motors Corp. v. Ruckelshaus, ${ }^{13}$ and Arrow Air, Inc. v. Dole, ${ }^{14}$ the District of Columbia Circuit gave legislative effect to interpretative rules adopted without notice and comment procedures.

In further blurring the distinction between legislative and imterpretative rules, General Motors and Arrow Air confront agencies with a dilemma. Following notice and comment procedures only ensures that a rule will have legislative effect if Congress has explicitly or implicitly delegated authority to make such rules. ${ }^{15}$ Imphicit delegations may be difficult to discern. ${ }^{16}$ If Congress has made an implicit delegation, notice and comment procedures may not be necessary to give the rule legislative effect. Thus, an agency cannot know with any certainty the sort of rule it has created until after the rule reaches the courts.

This article exammes how the line between legislative and interpretative rules became blurred and a class of interpretative rules with legisla-

7. See, e.g., id. at $424 \mathrm{n} .8$ (distinguishing agency acting as delegate of legislative power from agency interpreting statute as part of its administrative fnnction).

8. See, e.g., United States v. Mersky, 361 U.S. 431, 437-38 (1960) (rules created pursuant to statutory authority "have the force of law").

9. 5 U.S.C. § 553(b) (1982); see also Chrysler Corp. v. Brown, 441 U.S. 281, 302-03, 315 (1979) (legislative rules only have force of law when promulgated pursuant to notice and comment procedures of APA; interpretative rules need not follow notice and comment); infra note 180.

10. See Chisholm v. FCC, 538 F.2d 349, 393 (D.C. Cir.) (calling line between interpretative and legislative rules "tenuous"), cert. denied, 429 U.S. 890 (1976).

11. See infra notes $48-52$ and accompanying text.

12. See infra note 50.

13. 742 F.2d 1561, 1564-67 (D.C. Cir. 1984) (en banc), cert. denied, 105 S. Ct. 2153 (1985).

14. 784 F.2d 1118, 1122-26 (D.C. Cir. 1986).

15. See infra notes 11-70 and accompanying text.

16. See infra notes 74-116 and accompanying text. 
tive effect was born. ${ }^{17}$ It suggests how agencies can determine when Congress has imphicitly delegated to them the authority to make legislative rules. ${ }^{18}$ Finally, it proposes a way of restoring the match of procedure with authority that once distinguished interpretative rules from legislative ones: If the agency wishes legislative effect for a construction eligible for such effect, the rule must be adopted following notice to and participation by the public; if the agency does not provide for public participation, the rule will have only the authority and receive only the deference ifistorically due interpretative rules.

\section{The Genesis and Status of Interpretative Rules With LEGISLATIVE EFFECT}

\section{A. The Historical Distinction.}

A fundamental distinction in rules promulgated by administrative agencies is that drawn between legislative rules and interpretative rules. While the two classes are generally recognized, there is not general accord on how they should be defined. ${ }^{19}$ Professor Davis explains the difference in terms of authority: "A legislative rule is the product of an exercise of delegated legislative power to make law through rules. An interpretative rule is any rule an agency issues without exercising delegated legislative power to make law through rules."20

Professor Schwartz uses different terminology and also defines the classes shightly differently, distinguishing them not only in terms of authority but also in terms of content:

17. Courts have not recognized the discrete class "interpretative rule with legislative effect." In fact, the opinions that address this class of rules analyze them as if they were legislative rules and give them the controlling effect of such rules but fail to impose the rulemaking procedure required for legislative rules by 5 U.S.C. $\$ 553($ b). An exception to the courts' typical treatment occurred in General Motors Corp. v. Ruckelshaus, 742 F.2d 1561 (D.C. Cir. 1984) (en banc), cert. denied, 105 S. Ct. 2153 (1985), in which the rule was specifically held to be interpretative and yet given the controlling effect of a legislative rule, id. at 1564-67, and in Arrow Air, Inc. v. Dole, 784 F.2d 1118, 1122-26 (D.C. Cir. 1986); see also infra note 50 (discussing General Motors and Arrow Air).

For further discussion of the appropriateness of the label and whether the rules in question should actually be viewed as legislative, see infra notes $122,206-11$ and accompanying text.

18. See infra notes 75-117 and accompanying text.

19. See Chisholm v. FCC, 538 F.2d 349, 393 (D.C. Cir.) ("The distinction between an interpretative rule . . . and a legislative rule . . . is often tenuous. . . . No talismanic factor has emerged from the cases or the commentary as a guide for puzzled courts.") (citation omitted), cert. denied, 429 U.S. 890 (1976). For a recent listing of relevant factors, see Arrow Air, Inc. v. Dole, 784 F.2d 1118, 1122-23 (D.C. Cir. 1986) (listing as "general principles" the agency's label for the rule, the general language of the rule, whether the rule merely restates duties created by statute, whether the policy expressed in the rule has been consistently followed by the agency, and whether the agency's intent or the practical impact of the rule is to create new law, rights, or duties).

20. $2 \mathrm{~K}$. DAvis, supra note $1, \S 7: 8$, at 36 (emphasis added). 
Substantive rules are issued pursuant to statutory authority and implement the statute; they create law just as the statute itself does, by changing existing rights and obligations. An interpretive rule is a clarification or explanation of existing laws or regulations, rather than a substantive modification of them. Interpretive rules are statements as to what the agency thinks a statute or regulation means; they are statements issued to advise the public of the agency's construction of the law it administers. ${ }^{21}$

Schwartz's class of substantive rules appears coextensive with Davis's class of legislative rules. The definition Schwartz offers for interpretive rules, however, seems to extend only to a subclass of Davis's interpretative rules. 22

The difference between Schwartz's and Davis's definitions shonld not cause inuch difficulty, because the definitions are of different terms. The Attorney General's Manual, ${ }^{23}$ however, tracks Schwartz's definitional scheine but, as do Davis ${ }^{24}$ and the Administrative Procedure Act (the "APA" or the "Act"), ${ }^{25}$ uses "interpretative" rather than "interpretive." The Manual defines substantive rules as "rules, other than organizational or procedural ... ., issued by an agency pursuant to statutory authority and which implenent the statute . . ";26 it defines interpretative rules as "rules or statements issued by an agency to advise the public of the agency's construction of the statutes and rules which it administers." 27 Thus, it defines interpretative rules and legislative rules in terms of content and authority.

All three definitional schemes either state or imply that the issuance of interpretative rules is beyond the agency's explicitly delegated authority. ${ }^{28}$ Interpretative ruleınaking, nonetheless, is a practical necessity.

21. B. SchwarTZ, ADMINISTRATIVE LAW $§ 4.6$, at $158-59$ (2d ed. 1984) (footnotes omitted) (emphasis added).

22. Professor Davis does point out that "interpretative" might be misleading when an agency is not in fact interpreting anything. He appears, however, to limit the term to instances in which the agency gives meaning to a statute either by defining words and phrases or by filling gaps in the statute. See $2 \mathrm{~K}$. DAVIS, supra note $1, \S 7: 11$, at 56 ("When an administrator either gives meaning to a statute or answers a question that cannot be answered by finding the meaning in the statute, and when he states in general terms what he is doing, the statement is called 'an interpretative rule,' whether or not anything is in fact interpreted.").

23. UNited States Dep't Of Justice, ATtorney General's MANUAL on the AdminisTRATive Procedure Act (1947) [hereinafter ATtorney General's MANUal].

24. See supra note 20 and accompanying text.

25. 5 U.S.C. $\S \S 551-706$ (1982); see id. §553(b)(3)(A) (exempting interpretative rules from notice and comment requirements).

26. ATTORNEY GENERAL'S MANUAL, supra note 23 , at $30 \mathrm{n} .3$.

27. Id.

28. Professor Davis's definition of an interpretative rule, see supra text accompanying note 20 , expressly states that it is issued without delegated authority; as much is negatively implied in Professor Schwartz's definitions of interpretative and substantive rules, supra text aceompanying note 21, and in those of the Attorney General's Manual, supra text accompanying notes 26 and 27. But cf. 
"When Congress enacts a statute and assigns the administration of it to an agency, the agency encounters questions the statute does not answer and the agency must answer them. The agency heads must instruct their staffs what to do about such questions, and the instructions are interpretative rules." 29 Thus, while legislative rules grant new rights and impose new obligations, interpretative rules inerely explain the rights and obligations already created, albeit in inasked form, by the statute. ${ }^{30}$

Traditionally, the most important result of distinguishing interpretative from legislative rules on the basis of whether they were promulgated pursuant to delegated authority was that the courts accorded differing effect to the two types. " "[V]alid legislative rules have about the saine effect as vahid statutes and are therefore binding on courts, but . . . the courts in varying degrees refrain from substituting judgment as to the content of interpretative rules." 32 Thus, legislative rules inay be set aside only if "arbitrary, capricious, an abuse of discretion, or otherwise not in accordance with law ... [or] in excess of statutory jurisdiction, authority, or limitations, or short of statutory right.".33 Historically, however, "a court is not required to give effect to an interpretative regulation. Varying degrees of deference are accorded to administrative interpretations, based on such factors as the timing and consistency of the agency's position, and the nature of its expertise." 34 Although the factors that lead a court to grant deference to interpretative rules have been spelled out, how the degree of deference relates to the presence, absence, or salience of these factors remains unclear. ${ }^{35}$ Clarifying that standard of deference,

Morton v. Ruiz, 415 U.S. 199, 231 (1974) ("The power of an administrative agency to administer a congressionally created and funded program necessarily requires the formulation of policy and the making of rules to fill any gap left, implicitly or explicitly by Congress.").

29. 2 K. DAv1s, supra note 1, § 7:11, at 55; see also Morton v. Ruiz, 415 U.S. 199, 231 (1974).

30. Batterton v. Marshall, 648 F.2d 694 (D.C. Cir. 1980), discussed how legislative rules and interpretative rules affect existing rights and obligations. "Legislative rules . . . implement congressional intent; they effectuate statutory purposes. In so doing, they grant rights, impose obligations, or produce other significant effects on private interests." Id. at 701-02 (footnotes omitted). Interpretative rules, and other forms of what the court called "non-binding" action, "do not, however, foreclose alternate courses of action or conclusively affect rights of private parties." Id. at 702 (footnote omitted).

31. See Skidmore v. Swift \& Co., 323 U.S. 134, 140 (1944), quoted in General Elec. Co. v. Gilbert, 429 U.S. 125, 141-42 (1976); see also 2 K. DAVIS, supra note 1, $§: 13$.

32. $5 \mathrm{~K}$. DAV1S, supra note $1, \S 29: 20$, at 421 .

33. 5 U.S.C. $\S 706(2)$ (1982).

34. Batterton v. Francis, 432 U.S. 416, 425 n.9 (1977) (citing General Elec. Co. v. Gilbert, 429 U.S. 125, 141-45 (1976)); Morton v. Ruiz, 415 U.S. 199, 231-37 (1974); Skidmore v. Swift \& Co., 323 U.S. 134,140 (1944).

35. In 1979, Professor Davis stated:

Probably courts always have power to substitute their judgment for the content of interpretative rules. Such rules gain authoritative weight to the extent that courts refrain from substituting judgment. The theory is clear that, in absence of a delegation of legislative power to the agency, what the agency does in interpreting the law cannot be binding on the 
however, is not the goal of this article. Rather, the article examines the origin of those rules that appear to be interpretative insofar as they may be promulgated without notice and comment rulemaking and they construe congressional enactments, but which appear to have legislative effect and thus may only be set aside under the far stricter "arbitrary and capricious" standard. ${ }^{36}$

The legislative/interpretative distinction is of relatively recent vintage, as is the recognition of legislative rulemaking authority generally. As late as 1932, the Supreme Court was able to state: "That the legislative power of Congress cannot be delegated is, of course, clear."37 Professor Davis, however, traces the rise of legislative rules to $1911,{ }^{38}$ when the Supreme Court decided United States v. Grimaud. ${ }^{39}$ In upholding regulations promulgated by the Secretary of Agriculture controlling the grazing of sheep in forest preserves, the Court stated, "[W]hen Congress has legislated and indicated its will, it could give to those who were to act under such general provisions 'power to fill up the details' by the establishment of administrative rules and regulations ...."40 This statement obviously contradicted the anti-delegation view that the Court expressed in 1932, and the tension persisted until the discrepancy was resolved by a 1940 case, ${ }^{41}$ after which "[t]he way was open for agreeing that administrative rules may have force of law, and that the content of the rules may be administratively determined." 42

The recognition of interpretative rulemaking "authority" appears to have been less controversial, since that "authority" was not really a grant of power. At its base is the need of the administrative agency to say what

courts. A court which finds substitution of its judgment to be desirable always has power to substitute judgment for that of the agency in determining the content of interpretative rules.

...

Unquestionably one of the most important factors in each decision on what weight to give an interpretative rule is the degree of judicial agreement or disagreement with the rule.

2 K. DAvis, supra note $1, \S 7: 13$, at 59-60.

36. Normally, an agency rule would be arbitrary and capricious if the agency has relied on factors which Congress has not intended it to consider, entirely failed to consider an importaut aspect of the problem, offered an explanation for its decision that runs counter to the evidence before the agency, or is so implausible that it could not be ascribed to a difference in view or the product of agency expertise.

Motor Vehicle Mfrs. Ass'n v. State Farm Mut. Auto. Ins. Co., 463 U.S. 29, 43 (1983).

37. United States v. Shreveport Grain \& Elevator Co., 287 U.S. 77, 85 (1932).

38. See 2 K. DAvis, supra note $1, \S 7: 9$, at $44-45$.

39. 220 U.S. 506 (1911).

40. Id. at 517 .

41. Sunshine Anthracite Coal Co. v. Adkins, 310 U.S. 381, 398 (1940) ("Delegation by Congress has long been recognized as necessary in order that the exertion of legislative power does not become a futility.").

42. $2 \mathrm{~K}$. DAV1s, supra note $1, \S 7: 9$, at 44 . 
it beheves the law is and how that behef will guide its actions. ${ }^{43}$ The Court considered such interpretative rules in Skidmore v. Swift \& Co., ${ }^{44}$ stating:

We consider that the rulings, interpretations and opinions of the Administrator under this Act, while not controlling upon the courts by reason of their authority, do constitute a body of experience and informed judgment to which courts and litigants may properly resort for guidance. The weight of such a judgment in a particular case will depend upon the thoroughness evident in its consideration, the validity of its reasoning, its consistency with earher and later pronouncements, and all those factors which give it power to persuade, if lacking power to control. 45

Since the interpretative rule had no binding authority, and none of the three coordinate branches had delegated any of its power, there would be little cause for controversy.

As legislative rulemaking authority grew, the distinction between legislative and interpretative rules becane more important. The difference in their binding effect on the courts and on the rights of individuals became reflected in the differences in the procedures required in their adoption. Legislative rulemaking requires notice of the proposed rule in the Federal Register and an opportunity for interested persons to participate in the rulemaking through submission of written or oral comment or argument; ${ }^{46}$ interpretative rulemaking lacks these notice and comment requirements. ${ }^{47}$

In summary, administrative law caine to recognize interpretative rules as ones that clarified statutory rights and duties, were promulgated pursuant to an agency's inherent authority to express what it believed the statute meant, and were due varying degrees of deference from reviewing courts. It conceived of legislative rules as ones that expressed new rights and duties through the agency's exercise of delegated legislative authority and that were due the respect afforded to other laws by reviewing courts.

\section{B. The Distinction Blurred.}

In the past decade, the distinction has become blurred. Congress, the courts have found, may delegate the authority to interpret statutes,

43. See supra notes 28-30 and accompanying text. This justification rests on the view that interpretative rules are interpretive. The tension between that view and the Davis definition-a rule promulgated without exercising delegated legislative authority, see supra text accompanying note 20-did not exist until the advent of interpretative rules with legislative effect-rules that are interpretive but are issued pursuant to delegated legislative authority.

44. 323 U.S. 134 (1944).

45. Id. at 140 .

46. See 5 U.S.C. $\$ 553$ (1982).

47. See id. $\S 553(\mathrm{~b})(3)(\mathrm{A})$. 
and it may do so implicitly as well as explicitly. Furthermore under General Motors Corp. v. Ruckelshaus an agency, pursuant to its delegated authority, may promulgate interpretative rules that have legislative effect without following notice and comment rulemaking.

In Batterton v. Francis ${ }^{48}$ the Supreme Court decided that admimistrative interpretations of statutory terms-normally the subject of interpretative rules 49 -may under some circumstances have legislative effect. ${ }^{50}$ The Court stated:

Congress in $\S 407$ (a) [of the Social Security Act, 42 U.S.C. $\S 607$ (a) (1982)] expressly delegated to the Secretary [of Health, Education and Welfare] the power to prescribe standards for determining what constitutes "unemployment" for purposes of AFDC-UF eligibility. In a situation of this kind, Congress entrusts to the Secretary, rather than to the courts, the primary responsibility for interpreting the statutory term. In exercising that responsibility, the Secretary adopts regulations witl legislative effect. A reviewing court is not free to set aside those regulations simply because it would have interpreted the statute in a different manner. ${ }^{51}$

48. 432 U.S. 416 (1977).

49. See supra note 22 and accompanying text.

50. Granting legislative effect to rules that construe statutory terms raises the interesting question whether these agency constructions remain interpretative rules or should instead be considered legislative rules. Indeed, nothing in Batterton suggests that the Court viewed the rule as anything but legislative. Moreover, under Davis's distinction, see supra text accompanying note 20, the rule would be legislative, since the construction is "the product of an exercise of delegated legislative power." Although one may argue that this power is not "to make law through rules" but rather is a power to say what the law enacted by Congress means, the difference where Congress has left a gap and authorized its filling is semantic. Given the authoritative effect of rules, perhaps it is more appropriate to consider them legislative and require the notice and comment procedures of 5 U.S.C. $\S 553$ in their adoption. See infra notes 207-11 and accompanying text.

The United States Court of Appeals for the District of Columbia Circuit seems to have taken a different view in General Motors Corp. v. Ruckelshaus, 742 F.2d 1561 (D.C. Cir. 1984) (en banc), cert. denied, 105 S. Ct. 2153 (1985), and in Arrow Air, Inc. v. Dole, 784 F.2d 1118 (D.C. Cir. 1986). In considering an Environmental Protection Agency (EPA) regulation, the General Motors court first determined that it was an interpretative rule and that notice and comment were not required. General Motors, 742 F.2d at 1564-66. The court then granted the rule the authority due under the Supreme Court's decision in Chevron U.S.A. Inc. v. Natural Resources Defense Council, 467 U.S. 837 (1984). General Motors, 742 F.2d at 1566-67. The Arrow Air court followed the same patteru in upholding the Civil Aeronautics Board's interpretation of a regulation. Arrow Air, 784 F.2d at $1122-$ 26. There are three possible reasons for such treatment. The courts might have construed Chevron to apply to all agency constructions of statutes, regardless of whether there was a delegation of authority to construe the statute. But see infra text accompanying notes 59-71. Second, the courts might have found an implicit delegation of authority of the sort recognized in Chevron, see infra text accompanying note 61 , but decided that such a delegation does not necessarily make a statutory construction pursuant to the delegation a legislative rule. Third, of course, the courts might not have considered the question whether Chevron applies to agency constructions undertaken without an implicit delegation of authority, and thus may have cited Chevron merely as authority for granting great deference to an interpretative rule.

51. Batterton, 432 U.S. at 425 (emphasis in original). Although the Court found support in three of its earlier cases, those cases do not state as clearly the principle that an interpretation may 
In a footnote, the Court went on to state that these regulations have the "force and effect of law."s2

In the following years, the Court recognized explicit delegations to administrative agencies of the authority to construe statutes in many contexts and gave those constructions legislative effect. ${ }^{53}$ At the same time,

have legislative effect. In American Tel. \& Tel. Co. v. United States, 299 U.S. 232 (1936), the Court considered the Commumications Act of 1934, ch. 652, 48 Stat. 1064 (codified as amended in scattered sections of 15, 18, 46 \& 47 U.S.C.). Section 220 of the Act authorized the Federal Communications Commission (FCC) to prescribe, "in its discretion," the form in which accounts, records and memoranda were to be kept. Id. $\S 220$, 48 Stat. at 1078 (codified at 47 U.S.C. $\S 220$ (1982)). The Court rejected a challenge to the accounting procedures the FCC selected, stating:

This court is not at liberty to substitute its own discretion for that of administrative officers who have kept within the bounds of their administrative powers. To show that these have been exceeded in the field of action here involved, it is not enough that the prescribed system of accounts shall appcar to be unwise or burdensome or inferior to another. Error or unwisdom is not equivalent to abuse. What has been ordered must appear to be "so entirely at odds with fundamental principles of correct accounting" . . . as to be the expression of a whim rather than the exercise of judgment.

American Tel. \& Tel. Co., 299 U.S. at 236-37 (citations omitted).

In United States v. Mersky, -361 U.S. 431 (1960), the Court determined that the Tariff Act of 1930, ch. 497, 46 Stat. 590 (codified as amended at 19 U.S.C. $\S 1304$ (1982 \& Supp. II 1984)), authorized the Secretary of the Treasury to implement the Act by appropriate regulations and that the statute itself was not complete. Of the regulations adopted, the Court said:

Once promulgated, these regulations, called for by the statute itself, have the foree of lav, and violations thereof incur criminal prosecutions, just as if all the details had been incorporated into the congressional language. The result is that neither the statute nor the regulations are complete without the other, and only together do they have any force. Id. at 437-38.

In the third case on which the Batterton Court relied, Atchison, T. \& S.F. Ry. v. Scarlett, 300 U.S. 471 (1937), regulations adopted under the Federal Safety Appliance Act, ch. 160, 36 Stat. 298 (1910) (codified as amended at 45 U.S.C. $\$ \S 11-16$ (1982)), were in issue. The Act required, among other things, that railroad cars be equipped with ladders, and it required the Interstate Commerce Commission to designate the number, location, dimensions, and attachment of these ladders. The Court held that the ladder on which the plaintiff had been injured was not defective because it comported with the regulations in force and "[t]he regulation having been made by the commission in pursuance of constitutional statutory authority ... has the same foree as though prescribed in terms by the statute." Scarlett, 300 U.S. at 474.

The cases the Court cited clearly supported its conclusion. Batterton, then, was not a departure from earlier law, nor did it represent a novel conclusion. It did, however, present a particularly clear statement of the law in this area and became the precedential basis for further application of the principle. See, e.g., eases cited infra note 53.

52. Batterton, 432 U.S. at 425 n.9.

53. See, e.g., United States v. Morton, 467 U.S. 822, 834 (1984) ("Because Congress explicitly delegated authority to construe the statute [the child support and alimony provisions in 42 U.S.C. $\S 659$ (1982)] by regulation, in this case we mnst give the regulations legislative and hence controlling weight unless they are arbitrary, capricious, or plainly contrary to the statute.") (footnote omitted); Heckler v. Campbell, 461 U.S. 458, 466 (1983) ("Where, as here, the statute expressly entrusts the Secretary with the responsibility for implementing a provision [defining criteria for evaluating disability under the Social Security Act, 42 U.S.C. $\S 405$ (a) (1982)] by regulation, our review is limited to determining whether the regulations promulgated exceeded the Secretary's statutory authority and whether they are arbitrary and capricious.") (footnote omitted); Herweg v. Ray, 455 U.S. 265, 274-75 (1982) ("In view of Congress' explicit delegation of authority [in 42 U.S.C. $\S 1396 \mathrm{a}(\mathrm{a})(17)(\mathrm{B})(1982)]$ to give substance to the meaning of 'available [income and resources],' the 
the Court continued to assert the primacy of the judiciary in construing statutes ${ }^{54}$ in those instances in which the authority to construe the statute had not been delegated to the agency by Congress. ${ }^{55}$

After its decision in Batterton, the Court also expanded the area of delegated authority by recognizing the potential for implicit delegation. In Morton v. Ruiz, 56 the major issue was not the authority to promulgate rules but rather the responsibilities that accompany such authority. As part of its analysis, however, the Court stated, "The power of an administrative agency to administer a congressionally created and funded pro-

Secretary's definition of the term is ... entitled to 'legislative effect.' ") (citations omitted); Schweiker v. Gray Panthers, 453 U.S. 34, 43-44 (1981) (same provision and conclusion as in Herweg); INS v. Jong Ha Wang, 450 U.S. 139, 144 (1981) (per curiam) ("The crucial question in this case is what constitutes 'extreme hardship.' These words are not self-explanatory, and reasonable men could easily differ as to their construction. But the Act [Immigration and Nationality Act, § 244, ch. 477, 66 Stat. 163, 214 (1952) (codified as amended at 8 U.S.C. $\$ 1254(\mathrm{a})(1)(1982)$ )] commits their definition in the first instance to the Attorney General and his delegates, and their construction and application of this standard should not be overturned by a reviewing court simply because it may prefer another interpretation of the statute.").

54. See, e.g., Bureau of Alcohol, Tobacco \& Firearms v. Federal Labor Relations Auth., 464 U.S. 89, $98 \mathrm{n} .8$ (1983) ("When an agency's decision is premised on its understanding of a specific congressional intent . . . it engages in the quintessential judicial function of deciding what a statute means. In that case, the agency's mterpretation, particularly to the extent it rests on factual premises within its expertise, may be influential, but it cannot bind a court.") (citations onitted).

55. Henry Monaghan has explained that a court, in deferring to the administrative agency, has not abdieated its essential judicial function. The court still places limits on the agency interpretation by applying the "arbitrary and capricious" standard when the rule has legislative effect; in fact, the court interprets the law in determining that a rule is due legislative effect. As Professor Monaghan puts it:

The court's task is to fix the boundaries of delegated authority, an inquiry that includes defining the range of permissible criteria. In snch an empowering arrangement, responsibility for meaning is shared between court and agency; the judicial role is to specify what the statute cannot mean, and some of what it must mean, but not all that it does mean. In this context, the court is not abdicating its constitutional duty to "say what the law is" by deferring to agency interpretations of law: it is simply applying the law as "made" by the authorized law-inaking entity. Indeed, it would be violating legislative supremacy by failing to defer to the interpretation of an agency to the extent that the agency had been delegated law-making authority.

Monaghan, Marbury and the Administrative State, 83 Colum. L. Rev. 1, $27-28$ (1983). See also

Diver, Statutory Interpretation in the Administrative State, 133 U. PA. L. REv. 549,570 (1985):

Statutory law in itself is a source of positive law that may offer courts guidance in deterinining the correct mode of statutory interpretation. ... "The extent to which courts should defer to agency interpretations of law is ultimately 'a function of Congress' intent on the subject as revealed in the particular statutory scheme at issue." "The courts must, in other words, follow the legislature's "interpretative intent" [sic] as much as its substantive intent.

(quoting Process Gas Consuiners Group v. United States Dep't of Agriculture, 694 F.2d 778, 791 (D.C. Cir. 1982) (en banc) (quoting Constance v. Secretary of Health \& Human Servs., 672 F.2d 990, 995 (1st Cir. 1982), cert. denied, 461 U.S. 905 (1983), and Brest, The Misconceived Quest for the Original Understanding, 60 B.U.L. REv. 204, 215-16 (1980) (using the phrase "interpretive intent"))); see also Montana v. Clark, 749 F.2d 740, 745 (D.C. Cir. 1984) (discussing Monaghan's position), cert. denied, 106 S. Ct. 246 (1985).

56. 415 U.S. 199 (1974). 
gram necessarily requires the formulation of policy and the making of rules to fill any gap left, implicitly or explicitly, by Congress." 57 Although the Court spoke of implicit "gaps" ratlier than implicit grants of autlority, it later cited the opinion as one that acknowledged implicit grants of autliority. ${ }^{58}$

The significance of an implicit or explicit gap in a statute was central to the Court's opinion in Chevron U.S.A. Inc. v. Natural Resources Defense Council.59 There, after quoting the portion of Morton v. Ruiz quoted above, ${ }^{60}$ the Court wrote:

If Congress has explicitly left a gap for the agency to fill, there is an express delegation of authority to the agency to elucidate a specific provision of the statute by regulation. Such legislative regulations are given controlling weight unless they are arbitrary, capricious, or manifestly contrary to the statute. Sometimes the legislative delegation to an agency on a particular question is implicit rather than explicit. In such a case, a court may not substitute its own construction of a statutory provision for a reasonable interpretation made by the administrator of an agency. ${ }^{61}$

The juxtaposition of this language with that of Morton v. Ruiz must mean that an administrative construction controls not only when Congress has stated that there is a gap and that the agency is to fill it but also when Congress leaves an unexplained gap. In the latter case, by not speaking to the point or by speaking only ambiguously, Congress is taken to have implicitly delegated authority to the administrative agency to speak more precisely to tlie issue.

According to the Chevron Court, review of an agency's construction of the statute it administers centers on two questions:

First, always, is the question whether Congress has directly spoken to the precise question at issue. If the intent of Congress is clear, that is the end of the matter; for the court, as well as the agency, must give effect to the unambiguously expressed intent of Congress. If, however, the court determines Congress has not directly addressed the precise question at issue, the court does not simply impose its own construction on the statute, as would be necessary in the absence of an administrative interpretation. Rather, if the statute is silent or ambiguous with respect to the specific issue, the question for the court is whether the agency's answer is based on a permissible construction of the statute. ${ }^{62}$

\section{Id. at 231 .}

58. Chevron U.S.A. Inc. v. Natural Resources Defense Council, 467 U.S. 837, 843 (1984); see also infra notes 59-74 and accompanying text.

59. 467 U.S. 837 (1984).

60. Supra text accompanying note 57 .

61. Chevron, 467 U.S. at $843-44$ (footnotes omitted).

62. Id. at $842-43$ (footnotes omitted). 
Thus, the Court established a two-part test. ${ }^{63}$ First, a court determines whether the intent of Congress is clear. Second, if that intent is not clear, the court must give a reasonable agency construction not simply due deference, but controlling weight.

Chevron expands the range of agency constructions enjoying legislative effect. As before, regulations promulgated pursuant to exphicit delegations of authority to construe a statute receive such effect. In addition, the failure of Congress to speak clearly to the meaning of a statutory term must be deemed an imphicit delegation to the agency administering the particular statute to construe the ambiguous tern, and dictates that such constructions also be given legislative effect.

The Chevron Court reviewed and gave legislative effect to a rule adopted following notice and comment rulemaking. ${ }^{64}$ The Court did not, therefore, address whether interpretative rules promulgated under delegated authority without public participation should receive legislative effect. In General Motors Corp. v. Ruckelshaus ${ }^{65}$ and Arrow Air, Inc. v. Dole, ${ }^{66}$ the District of Columbia Circuit relied on Chevron to give legislative effect to rules promulgated pursuant to implicit delegations, but adopted without notice and comment procedures. These interpretations of Chevron complete the blurring of the distinction between legislative and interpretative rules.

Whether or not the lolding in Chevron follows as clearly from prior law as the opinion suggests, ${ }^{67}$ and wliether or not General Motors Corp. and Arrow Air follow from Chevron, the class of rules now considered to have legislative effect has certainly increased. Furtlierınore, the increase comes at the expense of clarity. Congress's implicit delegations of authority to an agency to construe a statute are more difficult to discern than its explicit delegations. ${ }^{68}$ The Chevron Court did find an imphicit

63. For a further discussion of this two-part test, see Note, A Framework for Judicial Review of an Agency's Statutory Interpretation: Chevron, U.S.A., Inc. v. Natural Resources Defense Council, 1985 Duke L.J. 469; see also The Supreme Court, 1983 Term, 98 HARv. L. REv. 87, 247 (1984).

64. See infra note 211.

65. 742 F.2d 156 (D.C. Cir. 1984) (en banc), cert. denied, 105 S. Ct. 2153 (1985). For further discussion of General Motors and how it appears to have interpreted Chevron, see supra note 50.

66. 784 F.2d 1118 (D.C. Cir. 1986). For further discussion of Arrow Air, see supra note 50.

67. See supra notes 48-61 and accompanying text (discussing Chevron Court's reliance on Morton y. Ruiz, which in turn relied on Batterton, which in turn relied on three earlier court opinions); see also The Supreme Court, 1983 Term, supra note 63, at 250 (describing Chevron as a "departure from precedent").

68. In Batterton v. Francis, 432 U.S. 416, 419 (1977), for example, the Court had no difficulty finding an explicit delegation to define "unemployment"; it traced the delegation to language requiring assistance to a needy child who "has been deprived of parental support or care by reason of the unemployment (as determined in accordance with standards prescribed by the Secretary) of his father," contained in the 1968 amendments to the Social Security Act, Pub. L. No. 90-248, 81 Stat. 821,882 (1968) (codified as amended at 42 U.S.C. $\$ \S 302-304$ (1982)) (emphasis added). For an- 
delegation in the term "stationary source" in the Clean Air Act Amendments of 1977.69 Although that term appears unambiguous, the Court considered the statutory language and legislative history unclear-an entire plant with multiple emitters of pollution (such as smokestacks) could be deemed either a single source or as many sources as there were, say, smokestacks. ${ }^{70}$ This was, then, an imphicit delegation to construe, and the Environmental Protection Agency (EPA) was authorized to fill the gap.

Likewise, the District of Columbia Circuit"1 apparently found an implicit delegation in the phrase "closely related to banking" in the Bank Holding Act of 1956.72 The court concluded that when the standard is "of sucli inherent imprecision . . . that a discretion of almost legislative scope was necessarily contemplated," the court's task is only to assure itself that the agency "acted reasonably, consistently and witl procedural regularity in giving content to the statutory standard."73

Despite these successful discoveries of implicit delegations, standards for the recognition of implicit delegations remain unclear. To determine the state of the law in the wake of Chevron, one must consider the factors that lead to a determination that Congress has spoken on the point at issue and, thus, for which the "judiciary is the final authority," 74 or, alternatively, that Congress lias not spoken or has spoken only ambiguously, thereby implicitly delegating controlling autliority to the agency to construe the statute reasonably.

\section{Determining the Existence of Legislative Effect.}

The starting point in the search for an implicit delegation of authority to construe a statute is revealed in the Chevron opinion itself. There the Court states that a court may not impose its own construction but inust, instead, determine whether the agency's construction is reasonable, and if so, give it controlling weight "if the statute is silent or ambiguous

other example, see INS v. Jong Ha Wang, 450 U.S. 139 (1981) (per curiam), in which the Court construed the phrase "a person whose deportation would, in the opinion of the Attorney General, result in extreme hardship," Immigration and Nationality Act, ch. 477, § 244, 66 Stat. 163, 214 (1952) (codified as amended at 8 U.S.C. $\$ 1254(a)(1)$ (1982)) (emphasis added). See Jong Ha Wang, 450 U.S. at 140.

69. Pub. L. No. 95-95, §§ 111(a), 129(b), 301(a), 91 Stat. 685, 704, 747, 770 (1977) (codified at 42 U.S.C. $\$ \S 7411(a)(3), 7502(b)(6), 7602(j)(1982))$.

70. Chevron, 467 U.S. at 861-64.

71. Association of Data Processing Serv. Orgs. v. Board of Governors, 745 F.2d 677 (D.C. Cir. 1984).

72. 12 U.S.C. $\S 1843(c)(8)(1982)$.

73. Association of Data Processing Serv. Orgs. v. Board of Governors, 745 F.2d 677, 697 (D.C. Cir. 1984).

74. Chevron, 467 U.S. at 843 n.9. 
with respect to the specific issue."75 So silence or ambiguity ${ }^{76}$ appears to be the key, yet not just any silence or ambiguity should suffice. In any case involving statutory construction, the parties offer different interpretations. Even the most common words may admit of two or more meanings and thus be ambiguous. ${ }^{77}$ If Congress has not addressed which of the offered constructions was intended, Congress has been silent on the specific issue. Surely the Chevron Court did not mean that courts should grant controlling weight to the agency position in all statutory construction questions. ${ }^{78}$

To state that Congress has been silent or ambiguous regarding a particular issue is actually to assert a conclusion that there has been an imphicit delegation of authority. In other words, once a court finds such a delegation, it will so signify by stating that the statute is ambiguous or silent on the contested statutory question. On the other hand, if the court has found no implicit delegation, it has become sufficiently convinced of its reading of the statute to state that no ambiguity or silence exists. Still, two (or more) meanings have been offered, so there is at least some ambiguity and silence (or at least no specific statement discoverable addressing which of the proffered meamings was intended). Of

75. Id. at 843 .

76. Professor Dickerson has pointed out that the label "ambiguity" is often attached to language that is vague or overly general rather than ambiguous. See Dickerson, The Diseases of Legislative Language, 1 HARV. J. ON LEGIS. 5, 10-13 (1964). Because the opinions use the term "ambiguity," it is also the label used here. Nonetheless, the factors discussed later in this article, see infra text accompanying notes 78-100, for identifying the type of ambiguity that indicates an implicit delegation are also intended to identify the sort of vagueness or generalization that implies such a delegation.

77. See, e.g., Community Nutrition Inst. v. Young, 757 F.2d 354 (D.C. Cir.), cert. granted, 106 S. Ct. 565 (1985). There the language in question was from 21 U.S.C. $\S 346$ (1982), a section of the Food, Drug and Cosmetics Act. That section concerned deleterious substances added to food and stated that "when such substance is . . . required or cannot be . . . avoided, the Secretary shall promulgate regulations limiting the quantity therein or theron to such extent as he finds necessary for the protection of public health." Id. The Food and Drug Administration (FDA) contended that "shall" should not be read to require the FDA to establish tolerances but rather to permit the agency to do so. Community Nutrition, 757 F.2d at 357. The court disagreed and found a requirement. Id. at 361.

78. See Chevron, 467 U.S. at $843 \mathrm{n} .9$ ("The judiciary is the final authority on issues of statutory construction and inust reject administrative constructions which are contrary to clear congressional intent."). If an agency construction were always given controlling weight, there would no longer be any distinction between the scopes of review afforded to legislative and interpretative rules. Yet the difference in review was one reason why Congress chose not to require the notice and comment procedure for the adoption of interpretative rules while requiring it in the adoption of legislative rules. See infra note 180 and accompanying text. If the distinction has now broken down and the existence of any ambiguity at all in the language of the statute is to be taken as a grant of controlling authority to the agency to construe the language, the scheine would be out of line with this early expression of legislative intent, and the proposal for public participation suggested herein, infra text at notes $147-80$, would be even more compelling. 
course, a clever enough lawyer will find ambiguity in any statute. ${ }^{79}$ It is clear, however, that although some ambiguity and silence exist in every statute, courts will not always conclude that the statute is "silent or ambiguous with respect to the specific issue." 80

One must search for the type of ambiguity or silence that will lead a court to find an implicit delegation. There appears to be two characteristics that, when present in sufficient degree, will cause a court to discern in an ambiguity the implicit delegation of authority to construe. When either factor is particularly strong, an implicit delegation should be found. Further, when either in itself might not be sufficient, the combination of the two may indicate an implicit delegation.

The first factor proposed plays a inajor role in the Supreme Court's analysis in Chevron: the degree to which the ainbiguity present in the statute reflects uncertainty about which of two competing policies is to carry the day. When Congress is motivated by competing policy concerus in enacting a statute, it is inore likely implicitly to delegate authority to interpret the statute and thereby balance the policies than when only one policy predominates and the question is simply how the policy underlying the statute applies to the issue at hand. ${ }^{81}$

The central role of this conflict of policy is laid out in Chevron. The Court first identifies in the legislative history two policy concerns: the allowance of reasonable economic growth and the protection of the environment. 82 The Court then discusses at length the respect that courts must give to an agency resolution of that policy conflict:

In these cases, the Administrator's interpretation represents a reasonable accommodation of manifestly competing interests and is entitled to deference: the regulatory scheme is technical and complex, the agency considered the matter in a detailed and reasoned fashion, and the decision involves reconciling conflicting policies. Congress intended

79. Not all claims of ambiguity arise from clever reading, but exhaustive parsing and reading will generally uncover some ambiguity. See, e.g., Fish, Working on the Chain Gang: Interpretation in the Law and in Literary Criticism, in THE POLITICS OF INTERPRETATION 271, 282-85 (W. Mitchell ed. 1983). The plausibility of the suggested ambiguity will vary from case to case, yet it is not only the totally implausible claim of ambiguity that will lead a court to substitute its own construction of the statute. Though strained (and later determined to be contrary to congressional intent), the FDA's contention in Community Nutrition Inst. v. Young, 757 F.2d 354 (D.C. Cir.), cert. granted, 106 S. Ct. 565 (1985), discussed supra note 77, that the statutory term "shall" mcant "to such extent as he finds necessary for the protection of public health," was not completely implausible.

80. Chevron, 467 U.S. at 843.

81. Just as a sufficiently clever lawyer will find ambiguity in any statute, that lawyer will also be able to identify competing policies advanced by the alternative readings. But inventiveness alone should not be enough. Only where Congress has expressed its interest in both policies should an implicit delegation be found on the basis of this factor.

82. Chevron, 467 U.S. at 851 . 
to accommodate both interests, but did not do so itself on the level of specificity presented by this case. Perhaps that body consciously desired the Administrator to strike the balance at this level, thinking that those with great expertise and charged with responsibility for administering the provision would be in a better position to do so; perhaps it simply did not consider the question at this level; and perhaps Congress was unable to forge a coalition on either side of the question, and those on each side decided to take their chances with the scheme devised by the agency. For judicial purposes it matters not which of these things occurred.

When a challenge to an agency construction of a statutory provision, fairly conceptualized, really centers on the wisdom of the agency's policy, rather than whether it is a reasonable choice within a gap left open by Congress, the challenge must fail. In such a case, federal judges-who have no constituency - have a duty to respect legitimate policy choices inade by those who do. ${ }^{83}$

Although the role of conflicting policies in discovering implicit delegations to construe statutory terins was first expressed in Chevron, the deferential treatment due agency pohcy reconciliation was already well established. In 1961, the Court wrote in United States $v$. Shimer:84

More than a half-century ago this Court declared that "where Congress has cominitted to the head of a department certain duties requiring the exercise of judgment and discretion, his action thereon, whether it involve questions of law or fact, will not be reviewed by the courts, unless he has exceeded his authority or this court should be of the opinion that his action was clearly wrong." ... This adinonition has been consistently followed by this Court whenever decision as to the ineaning or reach of a statute has involved reconciling conflicting policies, and a full understanding of the force of the statutory pohicy in the given situation has depended upon more than ordinary knowledge respecting the inatters subject to agency regulations. ${ }^{85}$

Thus, Shimer established that congressional delegation to an agency to resolve policy conflicts indicated that courts sliould accord deference to the agency resolution. This basis for deference has now reached the level of indicating an implicit delegation of autliority to construe the statute and to do so witlı legislative effect.

Since Chevron, the role of policy conflict in uncovering an implicit delegation has been recognized by the District of Columbia Circuit, tlough it has not been recognized to so definitely indicate an imphicit

83. Id. at 865 (footnotes omitted) (emphasis added).

84. 367 U.S. 374 (1961).

85. Id. at 381-82 (quoting Bates \& Guild Co. v. Payne, 194 U.S. 106, 108-09 (1904), and citing NLRB v. Seven-Up Bottling Co., 344 U.S. 344 (1953); SEC v. Chenery Corp., 332 U.S. 194 (1947); Republic Aviation Corp. v. NLRB, 324 U.S. 793 (1945); NLRB v. Hearst Publications, Inc., 322 U.S. 111 (1944); National Broadcasting Co. v. United States, 319 U.S. 190 (1943)). 
delegation as has been argued for here. In General Electric Uranium Management Corp. v. United States Department of Energy, 86 the court of appeals reviewed regulations prescribing fees for the disposal of spent nuclear fuel. It applied Chevron to determine that the fee rule was subject to the "arbitrary and capricious" standard due a statutory construction with legislative effect and concluded: "[W]e find that the statute is ambiguous with respect to the specific method of calculating the onetime fee, and that DOE's rule 'represents a reasonable accommodation of conflicting policies' served by the Act." 87 The court also found that the accommodation was not one that Congress would not have sanctioned and that DOE had fully and fairly considered the issue. ${ }^{88}$

The court in General Electric Uranium, while recognizing a role for a conflict of policy, apparently treated the presence of ambiguity and the presence of a policy conflict as independent factors leading to the same conclusion: that an imphicit delegation of authority to construe the statute had taken place. The two factors taken together do lead to such a conclusion, but the analysis should not depend on the concurrence of independent factors. Rather, the analysis should involve two steps. In the first, the court should determine the existence of ambiguity. Once ambiguity is found, in the second step the court should decide whether the ambiguity is the sort that indicates an implicit delegation to the agency to construe the statute. Since the General Electric Uranium court concluded that the ambiguity reflected a conflict of policy, the court could have concluded that there had been an implicit delegation.

The second factor proposed is the degree to which the term or phrase in which ambiguity occurs is technical or otherwise indicates the need for expertise in resolving the ambiguity. The need for agency expertise in interpreting a statutory term is, of course, a well-established factor in determining the degree of deference due an agency interpretative rule. For example, in discussing the contrast between legislative and interpretative rules, the Batterton v. Francis Court stated, "[A] court is not required to give effect to an interpretative regulation. Varying degrees of deference are accorded to administrative interpretations, based on such factors as the timing and consistency of the agency's position, and the nature of its expertise." 89 Just as the need for expertise in construing a

86. 764 F.2d 896 (D.C. Cir. 1985).

87. Id. at 905 (quoting Chevron, 467 U.S. at 845).

88. See General Elec. Uranium, 764 F.2d at 905.

89. Batterton v. Francis, 432 U.S. 416,425 n.9 (1977) (citing General Elec. Co. v. Gilbert, 429 U.S. 125, 141-45 (1976); Morton v. Ruiz, 415 U.S. 199, 231-37 (1974); Skidmore v. Swift \& Co., 323 U.S. 134, 140 (1944)); see also Rosado v. Wyman, 397 U.S. 397, 415 (1970) ("While . . . HEW's construction commands less than the usual deference that may be accorded an administrative interpretation based on its expertise, it is entitled to weight as the attempt of an expcrienced agency to 
statute plays a role in gauging the deference to be granted in reviewing an agency construction, that required expertise seems to merit a role in determining whether there has been an implicit delegation of authority to construe that warrants invoking the "arbitrary and capricious" standard and according the construction not mere deference, but controlling, legislative effect.

When Congress has used technical terms or phrases or ones otherwise requiring expertise in their construction, Congress nnay not have clearly understood the terms nor, correspondingly, intended a specific construction of them. ${ }^{90}$ When Congress lacked a clear understanding of a term or chose not to resolve technical ambiguity, it is unlikely that Congress intended that a court-like Congress, composed of laymenprovide the precise meaning it was unable or unwilling to supply. On the contrary, it is more likely that the Congress intended an agency with special expertise to supply the necessary clarification. Hence, through the use of a technical term, Congress may have imphied that the administrative agency is to have the authority to interpret that term.

Similarly, Congress may by adopting an imprecise standard imply that the special expertise of an administrative agency must be used to apply it.91 When Congress has attempted to be precise in enunciating the standard and the standard is not so technical that it requires expertise in application, Congress may have implicitly deemed the courts coinpetent to interpret the standard. Although there might still be factors counselling deference to an agency's interpretation, there would not be an implicit delegation, pursuant to which the court, under Chevron, would have to give controlling weight to the agency construction, reviewing it only under the "arbitrary and capricious" standard. On the other hand, when Congress has spoken with less precision and applying the standard calls for expertise, it is unlikely that Congress intended courts to supply

harmonize an obscure enactment with the basic structure of a program it administers."); Center for Auto Safety v. Ruckelshaus, 747 F.2d 1, 5 (D.C. Cir. 1984) ("A high degree [of deference] is appropriate ... when the agency's expertise can help in assessing the effects of competing interpretations upon the policies of the statute (and hence assessing the interpretation which a wise Congress should be presumed to have intended)."); National Wildlife Fed'n v. Gorsuch, 693 F.2d 156, 170 (D.C. Cir. 1982) ("[D]eference is not a unitary concept, to be applied with equal force to all issues in a case. If some issues involve scientific expertise and others do not, the agency will receive greater deference on the issues that do."').

90. If Congress did intend a specific construction, it could have added a definitional section to the statute sufficiently detailed to resolve the ambiguity.

91. See Association of Data Processing Serv. Orgs. v. Board v. Governors, 745 F.2d 677, 697 (D.C. Cir. 1984) (finding the standard "closely related to banking" so imprecise that it indicates Congress's intent to delegate to the agency authority to define it); see also infra notes $92-94$ and accompanying text. 
the missing precision. There appears to be an inplied grant to the agency involved to determine when the standard applies.

Association of Data Processing Service Organizations v. Board of Governors ${ }^{92}$ illustrates the role of this factor. There the court considered the standard "closely related to banking" in the Bank Holding Company Act of $1956 .{ }^{93}$ The court concluded that "atteinpting to exercise close and necessarily inexpert supervision of [tlie Board's] judgments ... would be particularly inappropriate under a governing statute such as this one, which commits it to tlie Board to apply a standard of sucli inherent imprecision ... that a discretion of almost legislative scope was necessarily contemplated."94 Altliough the language of the standard is not overly technical, it seems significant that Congress chose not to spell it out in greater detail. After all, Congress was certainly as capable as the courts of providing a more exact standard, and yet it cliose the imprecision of "closely related to banking." One inay reasonably conclude that Congress intended that the expert agency determine what activities were sufficiently closely related to banking to come within the scope of the statute. Thus, there was an implicit delegation of autlority to the agency to construe the statute.

Other cases uncovering an implicit delegation have not considered the degree to which the ainbiguity results from a teclinical term or indicates deference to technical expertise as inportant a factor as did the Data Processing court. The Chevron Court, however, noted in its analysis that the EPA had interpreted the regulation "in the context of implementing policy decisions in a teclinical and complex arena"9s and that the regulatory scheme was "technical and coinplex."96 Thus, although tlie Court focused on the choice between conflicting policies, it paid some attention to the need for agency expertise. Furtlermore, in invoking the Chevron approach the General Electric Uranium court did not refer to the need for techmical expertise, but the complexity of the statutory context in that case would, under the proposed analysis, support such a reference. ${ }^{97}$

It should be stressed that the two factors suggested may be treated in coinbination. Altliougli the cases already discussed apparently depended on only one factor, botli inay be important in a single case. In

92. 745 F.2d 677 (D.C. Cir. 1984).

93. 12 U.S.C. $\S 1843(\mathrm{c})(8)(1982)$.

94. Association of Data Processing Serv. Orgs., 745 F.2d at 697.

95. Chevron, 467 U.S. at 863.

96. Id. at 865 .

97. See supra notes $86-88$ and accompanying text. 
Montana v. Clark, 98 both factors were considered. The challenged regulations governed the distribution of surface mining reclamation funds. Under the regulations, monies for reclaiming "Indian land" outside reservations would be paid to the tribe, not the state; the statute, however, only called for payment to the tribe for reclamation of land in "Indian reservations." The court took into account both technical ambiguity and policy conflict. Considering potential technical ambiguity, the court determined that the construction "required no technical or specialized expertise." 99 Turning to potential policy conflict, however, the court noted conflicting congressional intentions about the locus of regulatory and administrative authority over surface mining and reclamation. The court stated, "The Secretary's commendable effort to reconcile the often starkly contradictory commands of the Act is both reasonable and consistent with the general intent of Congress." 100 Citing Chevron, ${ }^{101}$ and balancing these two factors in light of its own reading of the statute, the court granted deference to the agency construction.

While depending on Chevron for its reasoning, the court's analysis in Montana v. Clark conflicts with the Chevron approach discussed here. The court cited Chevron to support granting deference to an agency interpretation, which is not an uncommon use of Chevron. ${ }^{102}$ Nonetheless, Chevron held that when there is an implicit delegation of authority to construe, the agency construction is to be reviewed under the "arbitrary and capricious" standard, which goes beyond deference, and even beyond great deference. ${ }^{103}$ When Chevron applies, "a court may not substitute its own construction of a statutory provision for a reasonable interpretation made by the administrator of an agency." 104 In contrast, when a court grants deference, it is asserting its primary authority to say what the law is but chosing $\mathrm{m}$ its discretion to defer in varying degrees to the agency view. ${ }^{105}$ Thus, when an explicit or implicit delegation occurs, the law according to Chevron is that the agency has primary authority to constrne the statute, ${ }^{106}$ and the court has authority only to provide a very

98. 749 F.2d 740 (D.C. Cir. 1984), cert. denied, 106 S. Ct. 246 (1985).

99. Id. at 746 .

100. Id. at 752 .

101. Id. (citing Chevron, 467 U.S. at 844-45).

102. See, e.g., North Am. Telecommunications Ass'n v. FCC, 772 F.2d 1282, 1291 (7th Cir. 1985); Lieberman v. FTC, 771 F.2d 32, 37 (2d Cir. 1985); American Cyanamid Co. v. Young, 770 F.2d 1213, 1217 (D.C. Cir. 1985); Maine v. United States Dep't of Labor, 770 F.2d 236, 240 (1st Cir. 1985); Western Oil \& Gas Ass'n v. EPA, 767 F.2d 603, 606 (9th Cir. 1985).

103. See supra text accompanying note 61.

104. Chevron, 467 U.S. at 844 (footnote omitted).

105. See Batterton v. Francis, 432 U.S. 416, 425 n.9 (1977).

106. See Chevron, 467 U.S. at $843-44$, quoted supra text accompanying note 61 ; see also supra text accompanying note 55 . 
limited review, determining only whether the agency was within its authority and did not act arbitrarily or capriciously.

While it is clear that Chevron stands for more than simply a grant of deference, it is not clear that the case is always properly applied. In Montana v. Clark the two factors that have been discussed conflicted. ${ }^{107}$ Since a court could reasonably conclude from this conflict that no imphicit delegation occurred, it could properly grant the agency's interpretation mere deference rather than controlling weight. But if this is what the Montana court did, Chevron was not the most appropriate authority. ${ }^{108}$ General Motors Corp. v. Ruckelshaus ${ }^{109}$ presents a similar problem. The court expressly invoked Chevron and stated that the agency interpretation must merely be found to be sufficiently reasonable for it to be accepted by a reviewing court. ${ }^{110}$ Yet, in a later footnote responding to the dissent, the court shipped into a discussion about when courts should grant special deference to agency interpretations. ${ }^{111}$ As has been argued, factors counselling deference may also play a role in identifying an implicit delegation, ${ }^{112}$ but here the court had already found that Chevron apphied. Once the court held that it could "not simply impose its own construction on the statute," 113 no further discussion of deference was warranted.

The structure of the Chevron opinion may explain this confusion. Well after the opimion established that controlling weight is due an elucidation pursuant to a delegation and recognized that the delegation conferring this controlling weight may be implicit, ${ }^{114}$ the Chevron Court stated: "[T]lie Administrator's interpretation represents a reasonable accommodation of manifestly competing interests and is entitled to deference ...."115 Again, the interpretation did not need any deference; it already had controlling weight. ${ }^{116}$ In hight of the minor role of the later

107. See supra text accompanying notes $98-100$.

108. For cases that support granting deference to agency constructions of statutes, see, e.g., cases cited supra note 89 and accompanying text.

109. 742 F.2d 1561 (D.C. Cir. 1984) (en banc), cert. denied, 105 S. Ct. 2153 (1985).

110. Id. at 1567 .

111. Id. at 1572 n.16.

112. See supra text accompanying notes 89-97.

113. General Motors, 742 F.2d at 1567 (quoting Chevron, 467 U.S. at 843).

114. Chevron, 467 U.S. at $843-45$.

115. Id. at 865 .

116. A possibly inappropriate citation of Chevron also appears in Chemical Mfrs. Ass'n v. Natural Resources Defense Council, 105 S. Ct. 1102 (1985). Chevron was cited with a "see also" signal for the proposition that the view of an agency charged with the administration of a statute is due considerable deference and must be sustained if sufficiently rational. Id. at 1108 . Since the Chemical Manufacturers court granted deference, not legislative effect, to the interpretation, and since the citation to Cheyron was not in the strongest form, there may actually be no conflict with the approach argued for here. 
language, the choice of the word "deference" may not be significant. Chevron clearly applies only when an implicit or explicit delegation of authority to construe has taken place, and in those cases the delegation does more than merely increase the deference due; it grants the controlling weight that explicit delegations already enjoyed under Batterton $v$. Francis. 117 The only remaining difficulty should be in determining whether there has been such an implicit delegation, and the factors presented here are meant to provide some direction for that analysis.

\section{Public Participation In the Adoption of INTERPRetative RULES ENJOYING LEGISLATIVE EFFECT}

The range of interpretative rules to be given legislative effect has grown over the past several years. If courts do not apply the limitations discussed above in determining the sort of ambiguity that indicates implicit delegation, they are likely to find that many if not most interpretative rulings should have legislative effect. But even if courts do observe these limitations, the proportion of interpretative rules given legislative effect is likely to grow. In an atmosphere of deregulation, those regulations that are issued are more likely to involve technical matters ${ }^{118}$ requiring agency expertise, thus signaling implicit delegation of authority to the agency to construe statutory terms. ${ }^{119}$

This projected increase in the number of interpretative rules enjoying controlling force calls for a reexamination of what procedures should be required in their adoption. The Administrative Procedure Act exempts interpretative rules from notice and comment procedures. ${ }^{120}$ Their exemption was originally justified by the plenary judicial review interpretative rules faced. ${ }^{121}$ Interpretative rules with legislative effect, ${ }^{122}$

117. 432 U.S. 416 (1977), discussed supra notes $48-52,89$ and accompanying text.

118. While a deregulated industry would, by definition, be faced with fewer regulations, technical regulations would be more likely to survive, and the proportion of technical regulations would increase. For example, if deregulation removed nontechnical route and rate regulations in the transportation industries, technical regulations governing safety, for example, would predominate.

119. Several articles have addressed the scope of review to be given to rules designed to effect deregulation. See, e.g., Edwards, Judicial Review of Deregulation, 11 N. KY. L. REv. 229 (1984); Garland, Deregulation and Judicial Review, 98 HARv. L. REV. 507 (1985); O'Reilly, Judicial Review of Agency Deregulation: Alternatives and Problems for the Courts, 37 VAND. L. REV. 509 (1984); Sunstein, Deregulation and the Hard-Look Doctrine, 1983 SuP. CT. REv. 177. That question differs from the issue discussed here. This effort is concerned solely with interpretative rules, including those that might be issued under an already effected deregulatory regime.

120. 5 U.S.C. $\$ 553(b)(1982)$.

121. See Senate Comm. on the Judiciary, 79Th Cong., 2d Sess. (Comm. Print) in Administrative Procedure ACT: Legislative History 18 (1946) [hereinafter Senate Judiciary COMMITTEE PRINT], quoted infra text at note 180.

122. It should be stressed once again that the courts have not attached the label "interpretative rule with legislative effect" to the rules under discussion. The rules are all interpretive and, accord- 
however, no longer receive plenary court review. ${ }^{123}$ The role that had been served by postpromulgation review must now be served by preadoption public participation.

\section{A. Earlier Consideration of Public Participation in the Adoption of Interpretative Rules.}

The wisdom of the general exemption of interpretative rules from the notice and comment procedures of the Adıninistrative Procedure Act has not been unquestioned. Indeed, an attempt was made in 1965 to amend the Act by eliminating the exemptions for interpretative rules and general statements of policy. ${ }^{124}$ That attempt failed, and the hearing testimony of Professor Davis may offer the best explanation, and certainly offers a significant justification, for its failure. ${ }^{125}$ Professor Davis stated:

If the choice were merely between (a) party participation and (b) no party participation in the making of interpretative rules and general statements of policy, then I would favor party participation, and I would go along with the present draft on this point. But that is not the choice.... [N]othing in S. 1336 or in any other legislation can compel agencies to disclose all the policies that have become clarified in the minds of the administrators. ...

Indeed, ... one of the major failings of nost agencies is reluctance to clarify the law they administer. ... [E]verything should be done that can be done to encourage agencies to move toward earlier clarification. Two of the main inethods for such earlier clarification are interpretative rules and general statements of policy. ... The present draft, if adopted, will discourage agencies froin issuing either interpretative rules or general statements of policy.

Even though I prefer party participation, I do not want to pay the price in terms of discouraging more frequent use by the agencies of interpretative rules and general statements of policy. Therefore I favor

ing to the definitional scheme of the Attorney General's Manual, "interpretative." All of them are also legislative or substantive, however, because they are issued pursuant to statutory authority. See supra notes 20-27 and accompanying text. The label used here signifies that, while these rules have been granted legislative effect, the courts have not required any procedure beyond that necessary for the promulgation of interpretative rules.

123. It may, of course, be argued that interpretative rules never received true plenary review under the Administrative Procedure Act. As early as 1944, in Skidmore v. Swift \& Co., 323 U.S. 134 (1944), the Court had granted deference to agency constructions of statutes that the agency administered. See supra text at note 45 . Whether or not review of interpretative rules is properly characterized as plenary, however, it was certainly more strict than the review that is afforded interpretative rules with legislative effect under the "arbitrary and capricious" standard. See supra notes 32-36, 103-06 and accompanying text (discussing difference between granting deference and giving legislative effect to regulations).

124. See S. 1336, 89th Cong., 1st Sess. \& 4 (1965).

125. See Administrative Procedure Act: Hearings Before the Subcomm. on Administrative Practice and Procedure of the Senate Comm. on the Judiciary, 89th Cong., 1st Sess. 138, 150, 179 (1965) (statement of Professor Kenneth Culp Davis). 
continuing the present exemption. ${ }^{126}$

Professor Bonfield later echoed the concern of Professor Davis in coming to the same conclusion. ${ }^{127} \mathrm{He}$ discussed the argument that procedural restrictions would discourage adoption of the sort of rules and policy statments that agencies should be encouraged to make.128 Again, the theory appears to have been that if an agency had to follow notice and comment procedures to adopt interpretative rules and general statements of policy, its easiest course would be simply not to adopt such rules and policy statements. ${ }^{129}$ The public would then be left with agencies operating under secret policies and undisclosed interpretations of statutory terms.

Professor Bonfield offered additional reasons for maintaining an exemption for interpretative rules and general statements of policy. He argued, first, that elimination of the exemption would greatly increase agency workloads. ${ }^{130}$ Further, it would require notice and comment in instances in which there was little likelihood of public interest or of significant public contribution. ${ }^{131}$ Althougl that problem might be eliminated by qualifymg the exemption in the Administrative Procedure Act, ${ }^{132}$ Professor Bonfield argued that a more limited exemption would create uncertainty about the required procedures. ${ }^{133}$ Balancing these concerns against the benefits of public participation, ${ }^{134}$ he tentatively

126. Id. at 179 .

127. Bonfield, Some Tentative Thoughts on Public Participation in the Making of Interpretative Rules and General Statements of Policy Under the A.P.A., 23 AD. L. REv. 101 (1971).

128. Id. at $122-25$.

129. Id.

130. An active agency with a broad mandate may formally or informally instruct its staff on literally thousands of policy issues of all sorts each month; and it may formally or informally take positions on literally hundreds of questions with regard to the proper construction of the statutes or regulations it adininisters each month. Requiring adherence to $\S 553(b)$-(d) procedures for most, if not all, of these positions would necessarily vastly increase the agency work load and complicate it. This, in turn, would likely cause very substantial delay in the performance of the governinent's everyday functions, and increased costs in carrying on those functions.

Id. at 118. See also Swift, Interpretive Rules and the Legal Opinions of Government Attorneys, 33 AD. L. REv. 425 (1981) (arguing that even memoranda written by government attorneys are interpretative rules if they are adopted as representing the agency position on interpreting the law).

131. Bonfield, supra note 127 , at 118-19.

132. See 5 U.S.C. $\S 553(\mathrm{~b})(3)(B)$ (1982) (granting an exemption from notice and coinment procedures "when the agency for good cause finds (and incorporates the finding and a brief statement of reasons therefor in the rules issued) that notice and public procedure thereon are impracticable, unnecessary, or contrary to the public interest").

133. Bonfield, supra note 127, at 119.

134. Bonfield cites as the most important benefits the chance to elicit information from those best suited to offer it to aid intelligent rulenaking, the opportunity for the public to defend itself against proposed detrinental rules, and the likelihood that persons who have had a chance to participate in the making of a rule will be less inchined to attempt to sabotage the operation of the rule than persons who lacked an opportunity to participate. See id. at 104. 
concluded that the "exemptions for interpretative rules and general stateinents of policy are probably justified." 135

In a inore recent effort, Michael Asimow also considered the wisdom of dropping the exemption for interpretative rules and general policy statements. ${ }^{136} \mathrm{He}$, too, found value in public participation:

Public participation is no less necessary in the formulation of interpretive rules and policy statements than in legislative rulemaking. The agency is as much in need of information when it interprets its law or regulations, or when it formulates guidelines for exercising its discretion, as it is when it imposes binding norms on the public.... [T] he impact of many interpretations or policy statements can be as great as that of legislative rules. And the democratic values of public participation are as well served by requiring preadoption procedures in the formnlation of nonlegislative rules as im the adoption of legislative rüles. ${ }^{137}$

Nonetheless, he did not advocate the elimination of the exemption, finding the costs of elimination too great. ${ }^{138}$ Instead, he proposed that Congress annend the Administrative Procedure Act to require postadoption notice and comment for interpretative rules and policy stateinents. ${ }^{139}$

Charles Koch offered an alternative scheme of increased procedural requirements. ${ }^{140} \mathrm{He}$, too, recognized difficulties in eliminating the exeinption or in relying on the "good cause" exemption. ${ }^{141} \mathrm{He}$ suggested "the evolution of a broad range of abbreviated public procedures through judicial review of agencies' promulgation procedures to ensure that the choice of procedures comports with basic notions of fairness and does not abuse the agencies' discretion." ${ }^{142}$ The article preceded Vermont Yankee Nuclear Power Corp. v. Natural Resources Defense Council, ${ }^{143}$ and argued that the courts could inipose procedures in addition to those of the Administrative Procedure Act. ${ }^{144}$ After Vermont Yankee, this is

135. Id. at 127 .

136. Asimow, Public Participation in the Adoption of Interpretive Rules and Policy Statements, 75 Mich. L. Rev. 520 (1977).

137. Id. at 575 .

138. See id. at 575-78. Asimow mentioned the same costs listed by Davis, see supra text at note 126, and Bonfield, see supra text at notes 127-33.

139. See Asimow, supra note 136, at 578-84.

140. Koch, Public Procedures for the Promulgation of Interpretative Rules and General Statements of Policy, 64 GEO. L.J. 1047 (1976).

141. Id. at 1055-58.

142. Id. at 1054 .

143. 435 U.S. 519 (1978).

144. See Koch, supra note 140 , at $1058-59$ ("Several cases have suggested that the APA notice and comment procedures for legislative rules constitute only a minimum standard uponl which a court can require further particularized procedures. In the area of interpretative rules and general statements of policy, where the APA requires no public procedures, a judicial examination of the desirability of additional procedures would be appropriate.") (footnote omitted). 
apparently beyond the power of the judiciary, ${ }^{145}$ but Koch's scheme could be adopted through congressional amendment of the Act, though perhaps only with great difficnlty. ${ }^{146}$

\section{B. Public Participation Limited to Interpretative Rules With Legislative Effect.}

The proposal to be presented here is somewhat more modest. This article does not concern interpretative rules and policy statements in general. Rather, it focuses on interpretative rules given legislative effect, and the proposal may be restricted to that subset of rules. These are the sort for which additional preadoption procedures are most needed.

In addition to the factors already suggested that support imposition of notice and comment procedures in the adoption of all interpretative rules, ${ }^{147}$ the legislative history of the Administrative Procedure Act supplies a reason why interpretative rules with legislative effect should, $m$ particular, be adopted only after notice and comment. The Senate Judiciary Committee print ${ }^{148}$ for the seventy-ninth Congress's enactment of the Administrative Procedure Act gives as one reason for exempting interpretative rules from notice and comment procedure that " interpretative' rules-as merely interpretations of statutory provisions-are subject to plenary judicial review, whereas 'substantive' rules involve a maximum of administrative discretion." 149 Now, however, certain interpretative rules--those with legislative effect-no longer receive plenary judicial review. ${ }^{150}$ For those rules, therefore, one important rationale for the exemption from notice and comment is no longer valid.

In response, one might consider eliminating the exemption for those interpretative rules that enjoy legislative effect, but such an approach creates several problems. First, in many instances the agency cannot know that its interpretative rule will have legislative effect until a court has examined the relevant statutes to determine whether there has been an explicit or miplicit delegation of the authority to construe. This ap-

145. Vermont Yankee, 435 U.S. at 542-49 (administrative agencies are free from judicial interference to fashion their own rules of procedure; courts may not require that they follow procedures in addition to those prescribed in the APA); $c f$. infra notes 181-211 (discussing whether proposal made in this article could be judicially implemented consistent with Vermont Yankee).

146. Because Koch supported a particularized approach, drafting a statute requiring just the right amount of participation might well have been difficult.

147. See supra note 134 and text accompanying note 137 .

148. Senate Judiciary Committe Print, supra note 121 , at 11.

149. Id. at 18; see also infra note 180 (quoting similar statement by Sen. McCarren). But see supra note 123 (discussing the possibility that interpretative rules have not traditionally been subject to plenary judicial review).

150. See supra notes $48-117$ and accompanying text. 
proach, then, causes the same sort of uncertainty that Professor Bonfield objected to in proposals to eliminate the general exemption and force rehance on the good cause exemption. ${ }^{151}$ It forces an agency to predict whether a court will give its rule legislative effect. If the agency incorrectly decides that its rule would enjoy legislative effect, it has wasted its resources in notice and comment proceedings for a rule that, in any case, will enjoy only the deference due purely interpretative rules. ${ }^{152}$ If, on the other hand, the agency incorrectly decides that its rule does not have legislative effect and adopts the rule without notice and comment, the rule is arguably invalid under an approach that ehminates the exemption for interpretative rules with legislative effect. ${ }^{153}$

In some instances, of course, the agency can know that its interpretative rules will be found to have legislative effect. ${ }^{154}$ But even then the elimination of the exemption for all such rules raises problems. The problems, in fact, are the same ones that inake the elimination of the exemption for all interpretative rules unwise. Davis ${ }^{155}$ and Bonfield ${ }^{156}$ both argue that requiring preadoption notice and comment for interpretative rules could lead agencies to refuse to adopt such rules and to operate instead under secret interpretations of the statutes. Under this more limited exeinption under discussion, the reluctance attends only the adoption of rules that enjoy legislative effect, but the ill effect of the rule is qualitatively, if not quantitatively, the same.

Likewise, Professor Bonfield's other objections to the elinnination of the general exemption for interpretative rules ${ }^{157}$ also apply to the elimination of the exemption for interpretative rules enjoying legislative effect. Even when an agency knows that its interpretations enjoy legislative effect, questions will regularly arise about the proper construction of the statutes or regulations administered. ${ }^{158}$ If each such interpretation en-

151. See supra notes $132-33$ and accompanying text.

152. See supra note 34 and accompanying text.

153. The proposal under discussion requires notice and comment procedures for any rule enjoying legislative effect. Under this proposal, if a court determined that the adopted rule should enjoy legislative effect, it might invalidate the rule because the agency did not follow required procedure. Rather than finding invalidity, the court might grant the rule the deference due purely interpretative rules, with the same result that obtains under the proposal yet to be presented. Still, the other problems inherent in the proposal under discussion argue for its rejection, see infra notes 155 . 63 and accompanying text.

154. In certain instances the courts have already determined that agency regulations enjoy legislative effect. See, eg., cases cited supra note 53.

155. See supra text accompanying note 126.

156. See supra text accompanying note 128 .

157. See supra notes 127-35 and accompanying text.

158. Not all of the "literally hundreds" of interpretations per month that eaused Professor Bonfield concern about agencies' workload, see Bonfield, supra note 130 at 118 , enjoy legislative effect and would thus require notice and comment aceording to the proposal under discussion. Surely a 
tails notice and comment procedures, the work of the agency will be substantially delayed, and the cost of these necessary interpretations greatly increased. These costs are particularly unwarranted when hittle public interest or potential for significant public contribution exists, which will surely often be the case. ${ }^{159}$ Of course, the good cause exemptions might still be available, ${ }^{160}$ but the uncertainty about their applicability that led Bonfield to reject them as a solution ${ }^{161}$ obtains even under this more limited elimination of the exemption.

Professor Bonfield's analysis called for balancing the problems he catalogued against the benefits of public participation. ${ }^{162}$ For him, that balance appeared to favor retaining the exemption. ${ }^{163}$ If the exemption is eliminated only for rules enjoying legislative effect, as the magnitude of each problem lessens (since only a portion of the interpretative rules are affected), the benefits are proportionately reduced. Since the benefit of public participation will accrue only to precisely those rules that also continue to raise tlie problems Bonfield discussed, the balance remains the saine under this limited elimination of the exemption as under the general one, and thus the limited elimination approach should be rejected.

There is, however, an alternative proposal under which the benefits accrue witliout causing the probleins that result from the general elimination of the exemption. The agency should elect whether it wishes its interpretative rule to enjoy legislative effect. If the agency so chooses, then it must follow the procedures required of legislative rules. If the agency does not want its interpretative rule to have legislative effect, the procedures used in adopting interpretative rules will suffice.

Under this proposal, as under the rejected proposal, the agency may mistake the eligibility of its rule for legislative effect; however, the problems that result from such a mistake will be smaller. If the courts later disagree with the agency's behef that its rule should have controlling authority, resources will still have been wasted in providing for notice and comment when a rule has only the deferential effect of a purely interpretative rule. Under the proposal to eliminate the exemption for interpretative rules with legislative effect, however, the agency must pro-

significant number would, though, and the proportion might well grow as the law in this area evolves, see supra note 118 and accompanying text.

159. See Bonfield, supra note 127, at 118 . Bonfield was writing of interpretative rules in general, but even when the agency's construction has legislative effect, not all agency constructions will be of monumental importance.

160. See 5 U.S.C. $\S 553(b)(3)(B)(1982)$.

161. Bonfield, supra note 127 , at 119.

162. See supra note 134 and accompanying text.

163. See supra text accompanying note 135 . 
vide for notice and comment whenever it believes a rule would enjoy such effect; ${ }^{164}$ under the alternative proposed the agency is not so constrained. In addition to believing that the interpretative rule is due legislative effect, the agency must intend that the rule liave such effect before it will be required to follow notice and comment procedures. The agencies will tlius lrave an imcentive to expend what miglit turn out to be wasted time and effort only when their construction of a statute or regulation is so questionable tliat it might not be uplield under the standard of review due a purely interpretative rule, for only in such cases will the agency need to ensure that its interpretation is given legislative effect. Thus, agency resources will certainly be wasted less frequently than under tlie proposal to eliminate the exemption for all interpretative rules witlı legislative effect.

Alternatively, the agency may mistakenly believe that its proposed rule does not merit legislative effect when, in fact, the courts would find otlierwise. In tliat case, under this proposal, the agency will not provide notice and an opportunity for comment, and it is not required to do so even tlough its interpretative rule could enjoy legislative effect anyway. ${ }^{165}$ Notice and conıment procedures will be required only when the agency also intends legislative effect. The result is a valid rule that enjoys only the effect given a purely interpretative rule. The only cost to the agency is that it lias promulgated a rule enjoying less controlling effect thran it would have enjoyed if the agency had correctly interpreted the law and decided to follow notice and comment procedures. If the issue is sufficiently important to the agency, it may test the status due its rule by adopting it after notice and comment and arguing to tlie court that the rule is due controlling weight.

Nothing in the proposal prevents the agency from taking tliese two bites at tlie apple. If an agency adopts a construction without eniploying notice and comment, and the courts overturn the construction under a deference standard of review, ${ }^{166}$ the agency can adopt the saine interpretation after notice and comment, and test its interpretation in the courts under tlie "arbitrary and capricious" standard. This does not mean that an agency is overruling tlie courts. The first court decision recognizes that the law gives tlie agency the authority to construe the statute, but only after the proper procedure. Since tlie procedure has not been fol-

164. The rejected proposal required notice and comment whenever the interpretative rule was in fact due legislative effect. In other words, cases in which the agency had explicit or implicit authority to construe the statute in question, the proposal required notice and comment whether or not the agency intended that its rule be given such weight.

165. Under this proposal the agency merely has the option to obtain the effect for which the rule is eligible by instituting notice and comment procedures.

166. See supra note 34 and accompanying text. 
lowed and the rule does not stand under the deference standard, the rule is invalid. Once the proper procedure is followed, however, the second court must give controlling effect to the agency's interpretation of the disputed language as long as the agency determination is not arbitrary or capricious. ${ }^{167}$ To uphold the rule following notice and comment, the agency need not prove-and the second court need not find-that the first court erred in its determination of whose view controls. The second court can uphold the rule im spite of disagreement between the agency and the first court and, perhaps, between the second court and the first court over the correct construction of the statute. In the absence of notice and comment before adoption, the first court may have been entitled to substitute its judgment. ${ }^{168}$ When notice and comment precede adoption, the court can no longer do so.

Here, too, there will be areas in which the agency knows the extent of its authority to construe, ${ }^{169}$ and in those areas costly mistakes do not occur. More importantly, this approach avoids the costs associated with the general elimination of the exemption and with the elimination of the exemption for interpretative rules having legislative effect. The first problem, discussed by both Davis ${ }^{170}$ and Bonfield, ${ }^{171}$ was the possibility that agencies would avoid issuing interpretative rules if notice and cominent procedures were required. This proposal, however, contains no such requirement. If the agency does not wish to establish legislative effect for its construction, it will issue interpretations as it always has, and the interpretations will have as much validity as any other purely interpretative rules. Since publishing imterpretations entails no added difficulty, the agency has no incentive to keep secret its view of the statutes and regulations it administers. ${ }^{172}$

Likewise, Professor Bonfield's other objections to eliminating the exemption for interpretative rules do not apply here. While agencies will

167. See supra notes $55,59.63$ and accompanying text.

168. Courts may choose to defer to agency's interpretation of the statute based on various factors, including thoroughness of agency consideration. See supra note 34 and accompanying text.

169. See supra text accompanying notes 53,154 .

170. See supra text accompanying note 126.

171. See supra text accompanying notes $128-29$.

172. The situation described in the text highlights the importance of allowing the agency two bites at the apple. See supra notes 166-68 and accompanying text. If an agency interpretation promulgated without noticc and comment were invalidated under the deference standard and the agency was then not allowed to proinulgate the rule again after notice and comment so as to obtain the protection of the "arbitrary and capricious" standard, the agency inight choose to protect its future option to receive the higher level of protection by not issuing an interpretation in the first place. That is, rather than electing to issue a rule to be treated as purely interpretative as opposed to making the effort to obtain legislative effect, the agency might elect to keep its interpretation secret to preserve the later opportunity to obtain legislative effect. 
still issue many interpretative rules, ${ }^{173}$ even in instances in which the agency can obtain legislative effect for its construction, ${ }^{174}$ the agency need not provide for notice and comment except in the relatively few instances when it wishes its view to have legislative effect. In those cases the agency presumably has decided that the issue is important enough, and debatable enough, ${ }^{175}$ to warrant the extra effort required to achieve legislative effect. Furthermore, in the other cases, there is likely to be little public interest or potential for significant public contribution, and correspondingly httle likelihood of challenge, and thus little incentive for the agency to waste the expense of notice and comment on trivia. ${ }^{176}$

That is not to say that there is no cost to the proposal offered. Clearly, eacli rule for which public participation is allowed consumes more agency time and resources than are currently necessary to adopt an interpretative rule. These costs, however, must be balanced against the well-recognized value of public participation. ${ }^{177}$ Another advantage of

173. See supra note 130.

174. See supra note 158.

175. When the agency's construction will clearly survive judicial review under the deference standard for purely interpretative rules, there is no reason to make the effort required to obtain the greater protection of the "arbitrary and capricious" standard.

176. The situation described in the text further illustrates the importance of permitting an agency whose interpretative rule has not survived judicial review under a deference standard to represent the rule for review under the "arbitrary and capricious" standard following notice and comment rulemaking. $C f$. supra note 172 . Judicial challenge is possible even when the agency is most convinced of the legislative effect due its rule. If the agency cannot repromulgate after notice and comment, the agency may feel compelled to protect itself by following the additional procedure even for issues that generate little public interest or likelihood of significant public contribution.

177. See supra note 134 and text accompanying note 137; see also SENATE JUDICIARY COMMITTEE PRINT, supra note 121, at 20 ("'Public] participation ... in the rule-making process is essential in order to permit administrative agencies to inform themselves and to afford safeguards to private interests."); AdMINISTRATIVE CONFERENCE OF THE UNITED STATES, 1971-72 REPORT, Recommendation 28, at 59 (1972) ("Agency decisionmaking benefits from the additional perspectives provided by informed public participating."); Cramton, The Why, Where and How of Broadened Public Participation in the Administrative Process, 60 GEo. L.J. 525, 528, 530 (1972) ("Broadened public participation in the administrative process is necessary and desirable in order to provide an expanded set of ideas, rewards, and incentives for regulators ... [and] will lead to wiser and more informed decisions.") (footnote omitted); Gellhorn, Public Participation in Administrative Proceedings, 81 YALE L.J. 359, 361 (1972) ("There are a number of potential social advantages to public participation in administrative hearings. Public intervention can provide agencies with another dimension useful in assuring responsive and responsible decisions; it can serve as a safety valve allowing interested persons and groups to express their views before policies are announced and implemented; [and] it can ease the enforcement of administrative programs relying on public cooperation ...."); McLachlan, Democratizing the Administrative Process: Toward Increased Responsiveness, 13 ARIZ. L. REv. 835, 851 (1972) ("The merits of citizen participation in the decision-making processes of government are obvious. Such participation exemplifies the role of government in a democratic society and provides an adequate vehicle for the resolution of conflict and diversity. It gives the citizen an investment, indeed a right, to partake in the affairs of his government and supplies a means through which he may effectuate control over his own affairs and those of the society in which he lives. Participation by the public is an indication of both interest in government and an act of con- 
this proposal is that the agency itself must balance the cost agamst the importance of the rule's being afforded legislative effect. Presumably, the agency's view of the importance of the rule reflects the importance of allowing public participation in the adoption of the specific rule. Thus, increased adoption costs will accrue only in those cases in which the rule is particularly important to the agency, and, correspondingly, in which participation is particularly important to the public.

The election proposal not only avoids the problems inherent in the elimination of the exemption for interpretative rules in general or the more limited elimination for those rules having legislative effect; it has the additional advantage of restoring the original balance ${ }^{178}$ between public comment and judicial review. Legislative rules require public participation, unless good cause requires otherwise. ${ }^{179}$ The Administrative Procedure Act did not compel agencies to involve the public in formnlation of interpretative rules because, in the view held at that time, " imterpretative' rules-as merely interpretations of statutory provisions-are subject to plenary judicial review." 180 There are now rules, however, that escape both public participation and plenary review. Tliat result is clearly at odds with the seheme envisioned by the Administrative Procedure Act and should therefore be reinedied. The election proposal effects such a reinedy by requiring the agency planning to promulgate interpretative rules that are eligible for legislative effect to choose either to provide public participation or to face the possibility of plenary review.

\section{Implementing the Proposal.}

The question remains liow the election proposal could be implemented. Congress conld, of course, adopt the proposal as an amendinent

sent to the decisions of that government. It further insures that the government will receive adequate information.").

While the sources cited above do not directly address public participation in the adoption of interpretative rules, they do point out the value of public participation in general. Furthermore, it was not a difference in the value of public participation in each that led to the difference in the procedures required for the adoption of legislative rules and for interpretative rules. Ratler, it was the fact that interpretative rules would receive plenary judicial review that justified their adoption witlout notice and comment. See infra note 180 and accompanying text. Presumably, the values inherent in public participation would still attach to the adoption of interpretative rules, and in the case of interpretative rules witl legislative effect, the need would not be obviated by the availability of plenary judicial review.

178. See supra text accompanying notes 1-17.

179. See 5 U.S.C. $\$ 553(\mathrm{~b})(3)(B)$ (1982).

180. SenATE Judiciary COMMTTEe PRINT, supra note 121, at 18 (emphasis added); see also Administrative Procedure ACT: Legislative History, 79th Cong,, 2d Sess. 313 (1946) (statement of Sen. McCarren during floor debate) (interpretative rules exempt from preadoption notice and comment because "interpretative rules, being merely adaptations of interpretations of statutes, are subject to a more ample degree of judicial review"). 
to the APA, ${ }^{181}$ but the more interesting question is whether the courts could impose the proposal.

Standing in the way of judicial implementation is the Supreme Court's decision in Vermont Yankee Nuclear Power Corp. v. Natural Resources Defense Council. ${ }^{182}$ That opimon has not been received with universal acclaim. Notably, Professor Davis has criticized the soundness of the opinion, ${ }^{183}$ and its dictum ${ }^{184}$ in particular:

The Vermont Yankee opinion is largely one of those rare opinions in which a unanimous Supreme Court speaks with little or no authority. The Court lacks power to change the law through sweeping generalizations that are unsupported by close analysis. When the Court is unanimous, it has enormous power to change the law by carefully considering all facets of the problem before it and by systematically answermg the reasonable questions about the problem that an informed person would raise. The Vermont Yankee opinion is not that kind of opinion. ${ }^{185}$

Nonetheless, the opinion does represent the current state of the law and inust be dealt with.

The actual holding of Vermont Yankee does not address the validity of the proposal made here. The Court overturned a decision of the United States Court of Appeals for the District of Columbia Circuit requiring that the Atomic Energy Commission go beyond the notice and comment procedures prescribed in the APA's section 553. In contrast, this proposal merely extends the notice and comment requirements already provided in section 553 to reach interpretative rules with legislative effect; it does not graft additional procedures onto those notice and comment requirements. Dictum in the opening paragraph of Vermont Yankee, however, appears to cover the proposal:

[S]ection [553] of the Act established the maximum procedural requirements which Congress was willing to have the courts impose upon agencies in conducting rulemaking procedures. Agencies are free to grant additional procedural rights in the exercise of their discretion,

181. Cf. supra note 124 and accompanying text (discussing congressional attempt to amend APA in 1965).

182. 435 U.S. 519 (1978).

183. See $1 \mathrm{~K}$. DAvis, supra note $1, \S 6: 37$; Davis, Administrative Common Law and the Vermont Yankee Opinion, 1980 UTAH L. REv. 3.

184. See infra notes $186-87$ and accompanying text.

185. $1 \mathrm{~K}$. DAV1S, supra note $1, \S 6: 37$, at 616 . While the treatise's second edition was printed shortly after Vermont Yankee, further time for reflection did not appear to change Davis's view:

As of now, a year and a half later, the initial response of the legal community to the Vermont Yankee opinion is known, especially the response of the lower eourts. Would words of condemnation be changed if they could be rewritten to speak as of now?

The answer is no, but the answer is not free from doubt. And the doubt is whether the words should be even stronger, not whether they should be weakened.

Davis, supra note 183, at 17 (discussing the language quoted in the text). 
but reviewing courts are generally not free to impose them if the agencies have not chosen to grant them. ${ }^{186}$

This dictum appears to "resoundingly reject[] the notion that courts can require rulemaking procedures other than those specified in the APA." 187 Since the Act does not require a notice and comment procedure for the adoption of interpretative rules, the proposal may run afoul of Vermont Yankee if it is implemented by the courts rather than by Congress.

There are, however, several avenues around the problems raised by the Vermont Yankee dictum. Davis suggests that the "broad language may properly be narrowed to the specific problem [the Vermont Yankee Court] apparently had in mind," 188 namely, that full-blown adjudicatory hearings would become required for the adoption of any rule. ${ }^{189}$ While there does not appear to be any clear trend to limit Vermont Yankee so strongly, neither is the dictum being apphed im all the situations in which it could be. ${ }^{190}$

For example, the "substantial impact" test presents a doctrine that appears to be within the broad enbrace of Vermont Yankee's dictum but continues to enjoy an unstable existence in lower federal courts. ${ }^{191}$ It is of particular interest to the issue under discussion. Courts apply the "substantial impact" test to agency construction of statutes. If the construction has a substantial impact on individuals' rights and obligations, notice and comment procedures might be required. ${ }^{192}$

Two theories may justify the substantial impact test. First, an interpretative (or procedural) rule may have such a substantial impact that, despite the exemption from notice and comment requirements that is present in section 553, fundamental fairness requires notice and comment for its adoption. ${ }^{193}$ Second, the rule's substantial impact makes it a legis-

186. Vermont Yankee, 435 U.S. at 524 (footnote omitted).

187. McGowan, The Administrative Conference: Guardian and Guide of the Regulatory Process, 53 GEo. WASH. L. REv. 67, 78-79 (1984) (footnote omitted).

188. Davis, supra note 183 , at 15.

189. Vermont Yankee, 435 U.S, at 548.

190. Davis notes: "The Supreme Court's opinion left some escape hatches open, and the lower courts are rather uniformly using them." Davis, supra note 183, at 15.

191. See infra note 193; see also infra notes 196-97 and accompanying text.

192. See, e.g., Action on Smoking \& Health v. Civil Aeronautics Bd., 699 F.2d 1209, 1216 n.47 (D.C. Cir. 1983) ('The 'substantial impact' test determines the applicability of $\S 553$ procedures essentially by asking whether the agency action carries substantial impact on the rights and interests of private parties.").

193. See, e.g., Independent Broker-Dealers' Trade Ass'n v. SEC, 442 F.2d 132, 144 (D.C. Cir.) ("Elementary fairness may well require that reasonable opportunity be given [for notice and comment] by those materially affected [by the agency action]."), cert. denied, 404 U.S. 828 (1971); see also Pharmaceutical Mfrs. Ass'n v. Finch, 307 F. Supp. 858, 863-65 (D. Del. 1970) (stressing importance to regulated industry in applying substantial impact test); National Motor Freight Traffic 
lative rule, for which the APA requires notice and comment. ${ }^{194}$ This second theory conflicts with the Davis view of the distinction between interpretative and legislative rules, ${ }^{195}$ and if the "substantial impact" test is to have theoretical footing, it would appear best to rely on the first theory. Yet it is the first theory that is called into question by Vermont Yankee. If the rule is interpretative, the express terms of section 553 of the APA exempt it from the notice and comment requirements of that provision. To require notice and comment, even after finding substantial impact, is to require procedure beyond that specified in the Act.

Although the substantial impact test requires procedures in addition to those specified in the APA and hence is contrary to the dictum in Vermont Yankee, there appears to be confusion in the lower courts about its continued viability. Views differ among the circuits, ${ }^{196}$ and even within the District of Columbia Circuit there appears to be contradictory opinions. ${ }^{197}$ While recognizing the problem, Davis advises that "courts should probably go on assuming that when they find that justice so re-

Ass'n v. United States, 268 F. Supp. 90, $95-96$ (D.D.C. 1967), aff'd mem., 393 U.S. 18 (1968); 2 K. DAVIS, supra note 1, $\S 7: 17$, at 77 (favoring courts' requiring notice and comment procedure on ground that "elenientary fairness requires [it] as a matter of common law"); Note, The Substantial Impact Test: Victim of the Fallout from Vermont Yankee, 53 GEO. WASH. L. REv, 118, 123-26 (1984) (discussing the development of the "substantial impact" test from notions of fundamental faimess).

194. See, eg., Brown Express, Inc. v. United States, 607 F.2d 695, 700 (5th Cir. 1979) (notice and conıment required where rule created new obligations); Reynolds Metals Co. v. Rumsfeld, 564 F.2d 663, 669 (4th Cir. 1977) (notice and comment not required because rule did not create additional rights or obligations), cert. denied, 435 U.S. 995 (1978); American Bancorp. v. Board of Governors, 509 F.2d 29, 34-35 (8th Cir. 1974) (notice and comment not required where regulation merely clarified obligations implicit in previous regulation).

195. See supra text at note 20; see also American Postal Workers Union v. United States Postal Serv., 707 F.2d 548, 560 (D.C. Cir. 1983) ("As Professor Davis has noted, the impact of a rule has no bearing on whether it is legislative or interpretative; interpretative rules may have a substantial inupact on the rights of individuals.") (citing $2 \mathrm{~K}$. DAvis, supra note 1, § 7:8, at 39), cert. denied, 465 U.S. 1100 (1984).

196. For a discussion of cases from the various circuits, see Note, supra note 193.

197. Compare American Postal Workers Union v. United States Postal Serv., 707 F.2d 548, 560 (D.C. Cir. 1983) ("[T]he substantial impact of the new rule . . . does not transform it into a legislative rule. As an interpretative rule, ... [it] is exempt from the rulemaking requirements of the APA ...."), cert. denied, 465 U.S. 1100 (1984) and Cabais v. Egger, 690 F.2d 234, 237 (D.C. Cir. 1982) ("Simply because agency action [ruleniaking] has substantial impact does not nean it is subject to notice and comnent if it is otherwise expressly exenupt under the APA.") (footnote omitted) with Neighborhood TV Co. v. FCC, 742 F.2d 629, 637 (D.C. Cir. 1984) (citing National Ass'n of Homc Health Agencies v. Schweiker, 690 F.2d 932, 949 (D.C. Cir. 1982), cert. denied, 459 U.S. 1205 (1983), for the proposition that the "APA exenuption fron the notice and comment requirement does not apply to agency action which has a substantial impact on substantive rights and interests") and Action on Smoking \& Health v. Civil Aeronautics Bd., 699 F.2d 1209, 1216 n.47 (D.C. Cir. 1983) ('The 'substantial impact' test determines the applicability of $\S 553$ procedures essentially by asking whether the agency action carries substantial impact on the rights and interests of private parties."). 
quires they may properly hold that a particular intepretative rule having substantial impact is invalid unless issued after procedure of notice and comments."198

Davis's view does not seem consistent with the scheme of the APA or with the Supreme Court's sense of that scheme. The substantial impact test applies to the interpretative rules expressly exempted from the Act's notice and comment procedures. As the Court explained in Chrysler Corp. v. Brown, 199 "the APA is 'a formula upon which opposing social and pohtical forces have come to rest," "200 and "[c]ourts upset that balance when they override informed choice of procedures and impose obhigations not required by the APA."201 As part of this formula, Congress has already struck the balance with respect to interpretative rules, whatever their impact. The courts should maintain that balance.

Fortunately, one need not adopt Davis's view to argue that the proposal made here could be judicially imposed. ${ }^{202}$ Instead, one begins by recognizing that in enacting the APA Congress did not strike a balance with respect to interpretative rules with legislative effect because it did not contemplate the existence of such rules. Interpretative rules with legislative effect are a creation of the judiciary, derived from the courts' interpretations of various statutes as delegating authority to construe statutory terms. ${ }^{203}$ Those statutes also do not specify what procedure agencies should follow in proinulgating rules pursuant to the authority delegated. Since neither the APA nor the statutes that delegate authority express how Congress wishes the balance to be struck in the case of interpretative rules with legislative effect, courts upset no balance and override no informed choice of Congress in prescribing procedures for this judicially created ${ }^{204}$ class of rules. ${ }^{205}$

198. $2 \mathrm{~K}$. DAVIS, supra note $1, \S 7: 19$, at 94.

199. 441 U.S. 281 (1979).

200. Id. at 313 (quoting Vermont Yankee, 435 U.S. at 547 (quoting Wong Yang Sung v. McGrath, 339 U.S. 33, 40 (1950))).

201. Id. at 313 .

202. Of course, if the Davis view were to prevail, and notice and comment procedure could be required of interpretative rules having a substantial inpact, this would add further weight to the argument for a notice and comment requirement for interpretative rules with legislative effect. For one thing, the Vermont Yankee dictuin would have been substantially limited and would not present the problem it now does. Secondly, the fact that the agency interpretation in such a rule is given legislative effect and avoids plenary review might itself be viewed as constituting substantial impact.

203. See supra notes $48-74$ and accoinpanying text.

204. Congress, of course, played a role in passing the legislation found to delegate the authority to construe. Congress did not, however, expressly recognize a new class of rule. The judiciary has set these rules aside as a new class that are interpretative insofar as they construe statutory terms, but see infra notes 207-11 and accompanying text, but not interpretative insofar as they are exercises of delegated authority, see supra text accompanying note 20 , and are not subject to plenary judicial review, see supra note 180 and accompanying text. 
One might avoid even the need to make this argument, however. Perhaps the best approach is to realize that interpretative rules with legislative effect ${ }^{206}$ are, in fact, legislative rules. Classifying these rules as legislative comports with Davis's view of the distinction: "A legislative rule is the product of an exercise of delegated legislative power to make law through rules. An interpretative rule is any rule an agency issues without exercising delegated legislative power to make law through rules."207

Classifying these rules in terms of the source of authority on which they are based and the effect given them by courts also appears to be what Congress had in mind in exempting interpretative rules from section 553 because it believed them subject to plenary judicial review. 208 Thus, a rule is not interpretative because it interprets, but instead because it is not made pursuant to delegated authority and hence does not enjoy controlling effect. ${ }^{209}$ The courts have already found that interpretative rules with legislative effect are promulgated pursuant to delegated authority to make law through rules. ${ }^{210}$ Therefore, they should take the next step and recognize that this characteristic makes this class of rules legislative and subject to the notice and comment requirements of section 553. In other words, these rules should be deeined legislative when the agency chooses to exercise its delegated authority and promulgate a rule with legislative effect, and when it so chooses, it must also provide for public participation. ${ }^{211}$

205. A court creates no new procedure when it decides that an interpretative rule with legislative effect is a legislative rule. Rather, having decided that there are rules somewhere between the classes established in the APA and for which the APA does not specify any procedure, the court merely decides which of the APA rulemaking procedures is more appropriate for the new class.

206. See supra notes $12,13,122$.

207. 2 K. DAVIS, supra note $1, \S 7: 8$, at 36 .

208. See supra note 180 and accompanying text.

209. See supra notes 28-34 and accompanying text. Davis does appear to limit interpretative rules to those that express what the agency believes the law is, although he believes that these expressions sometimes are not really interpretations of anything. See supra note 22 and accompanying text. Of course, even if only interpretations can be interpretative rules, that does not mean that all interpretations are interpretative rules.

210. See supra notes $48-74$ and accompanying text.

211. The conclusion in the text appears to be supported by Professor Mayton's recent advocacy of the "force of law" test to determine whether notice and comment are required in the promulgation of a rule. See Mayton, $A$ Concept of a Rule and the "Substantial Impact" Test in Rulemaking, 33 EMORY L.J. 889 (1984). Applied to the rules in question here, his analysis rests on the grant of authority to issue rules with the force of law together with the agency's intent that the rules have such force. See id. at 906 . These rules are issued pursuant to a delegation of authority, and the agency's election shows its intent while also dictating the procedure that the "force of law" test would require.

The analysis of the United States Court of Appeals for the District of Columbia Circuit in General Motors Corp. v. Ruckelshaus, 742 F.2d 1561, 1566 (D.C. Cir. 1984) (en banc) (implying that Chevron dictates at least great deferencc, and possibly legislative effect, to interpretative rule 


\section{ConClusion}

Interpretative rules with legislative effect are an important class of administrative rules whose importance is likely to grow. The importance of the class and the controlling effect given to rules in this class require that the rules be promulgated only following public participation. The administrative agency should be put to the election whether to obtain legislative effect by providing for notice and comment or to forego this effect and adopt the rule without notice and comment. The election approach avoids the problems that have led commentators to argue that public participation should not be required of interpretative rules in general; it also restores the traditional balance in which all rules are subject to either public participation or plenary review. Furthermore, courts may impose the requirement of public participation under one of two theories: by invoking the novelty and judicial origin of this class of rules to justify judicial determination of the proper APA promulgation procedures, or by recognizing that these rules are actually legislative rules in interpretative clothing.

promulgated without notice and comment), cert. denied, $105 \mathrm{~S}$. Ct. 2153 (1985), might be viewed as contrary to the position taken here. That court's similar analysis in Arrow Air, Inc. v. Dole, 784 F.2d 1118 (D.C. Cir. 1986), seems even more clearly contrary. See id. at 1126 (where two reasonable interpretations of statute are possible, agency's view "must" prevail, citing Chevron, 467 U.S. at 84344). The analysis of these two cases may also, however, be explained in a noncontradictory manner. See supra note 50.

The presence or absence of notice and comment does not appear to have played a role in the reasoning in the other cases cited in tracing the development of legislative effect for interpretative rules. In Chevron, the Court cited the Federal Register publication of the regulations under consideration; that publication indicated that comments had been received by the agency. See Chevron, 467 U.S. at 841 (citing 46 Fed. Reg. 50,766 (1981)). The provision of notice and comment is not, however, mentioned as the justification for a grant of legislative effect, and there is no indication that had there not been notice and comment there would have been no legislative effect.

In Morton v. Ruiz, 415 U.S. 199 (1974), while discussing internal agency procedures rather than APA requirements, the Court noted with regard to the regulation at issue that "at oral argument the Government conceded that for this to be a 'real legislative rule,' itself endowed with the force of law, it should be published in the Federal Register." Id. at 235. Thus, the government may not have been willing to go as far as is proposed here, since its position required only publication rather than notice and comment. 